\title{
Givetian rugose corals from the Zemmour in Mauritania
}

\author{
Marie COEN-AUBERT
}

DO Terre et Histoire de la Vie (Evolution de la Paléobiosphère), Institut royal des Sciences naturelles de Belgique, rue Vautier 29, B-1000 Bruxelles, Belgium; Marie.Coen-Aubert@naturalsciences.be.

ABSTRACT. Ten species and three forms of rugose corals from the Givetian of the Zemmour in Northern Mauritania are described and illustrated, confirming the age of the coral levels intercalated in a succession of mainly detrital deposits more than $300 \mathrm{~m}$ thick. Five taxa are new: Acanthophyllum filiforme n. sp., A. sougyi n. sp., Charactophyllum soraufi n. sp., C. mauritanicum n. sp. and Macgeea tourneuri $\mathrm{n}$. sp. The coral fauna of the Zemmour is characterized by some North Gondwanan species such as Siphonophrentis kullmanni (Birenheide, 1978). However, there are also several species defined in the Givetian of Western and Eastern Europe which are useful for stratigraphic correlations, especially Acanthophyllum heterophyllum (MilneEdwards \& Haime, 1851), Sociophyllum isactis (Frech, 1886), Spinophyllum spongiosum (Schlüter, 1889) and Argutastrea briceae (Rohart, 1988). Farther to the east, the relationships with the Givetian of Russia, China and Australia are only occasional. Additionally, the fauna of the Zemmour is unusual due to the occurrence of the rather rare genera Moravophyllum Kettnerova, 1932, Charactophyllum Simpson, 1900 and Iowaphyllum Stumm, 1949.

KEYWORDS: Rugosa, taxonomy, stratigraphy, Givetian, palaeobiogeography, Gondwana.

\section{Introduction}

The Givetian of the Zemmour is well exposed to the north of Bir Moghreim (formerly Fort Trinquet), in the northern part of Mauritania (Fig. 1). It was investigated in great detail, from a lithologic and biostratigraphic point of view, by Sougy (1964) who gathered among others a large collection of rugose corals in the early Sixties. Part of these specimens was sent to Professor Marius Lecompte of the Catholic University of Louvain in Belgium and is now stored in the Collection of Palaeontology of the Institut royal des Sciences naturelles de Belgique at Brussels.

Three Givetian species of massive rugose corals have been identified in the Zemmour by Coen-Aubert (2013); these are Phillipsastrea torreana (Milne-Edwards \& Haime, 1851), $P$. kergarvanensis Coen-Aubert \& Plusquellec, 2007 and $P$. sobolewi (Rozkowska, 1956). Besides two massive colonies belonging to Argutastrea Crickmay, 1960 and Iowaphyllum Stumm, 1949, a diverse fauna of mostly solitary rugose corals is described in this paper. Unfortunately, the Givetian of the Zemmour is not dated or subdivided with much precision as there are nearly no recent studies on other groups of fossils and as there are no block samples available for the extraction of microfossils such as conodonts.

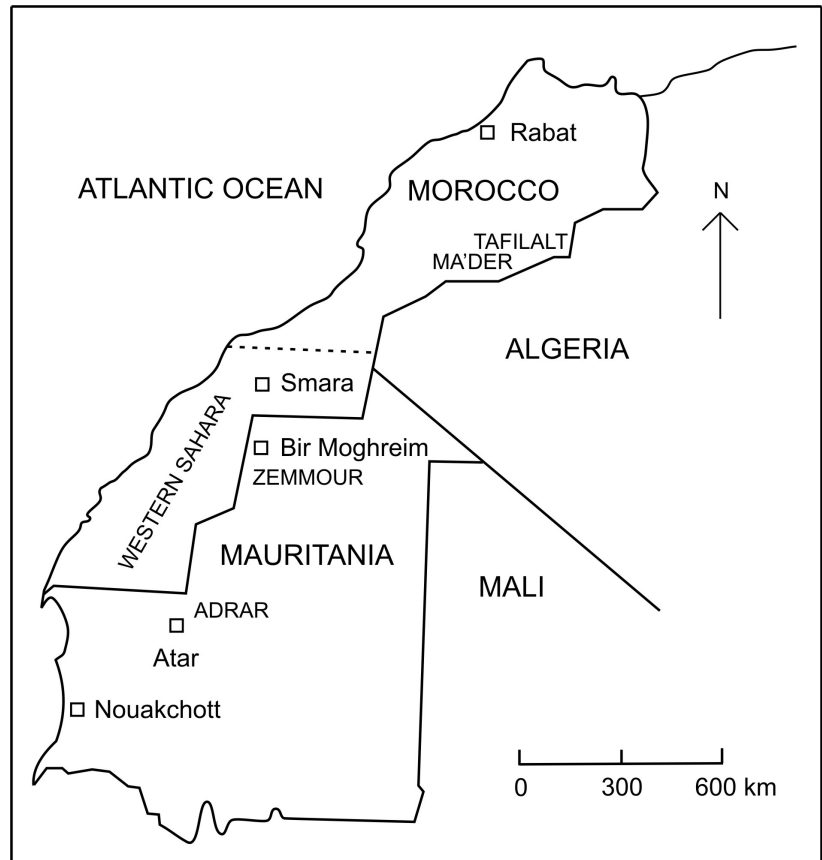

Figure 1. General setting in Northwestern Africa.

\section{Geological setting and material}

The Givetian of the Zemmour has been summarized with some detail by Coen-Aubert (2013), on the basis of the three main sections investigated by Sougy (1964): sections E4 of Tighirt, F5 of Aguelt Nebka and Amgli el Harra and F6 of Amgli el Harra and Amgli Zguilma (Fig. 2). Additionally, some rugose corals studied herein come from the sections of Douik el Akhdar and D13 of Aguelt Oudiate el Khyam where only the base of this succession is exposed.

Lithologically, the Givetian of the Zemmour can be subdivided into two parts above unit 81 of Sougy (1964) which was named Cabrieroceras Limestone as it contains the goniatite C. crispiformis (Fig. 3). For Sougy (1964), this level corresponds to the base of the Givetian. However, as mentioned by Tourneur (1987), C. crispiformis occurs in the middle part of the Tortodus kockelianus conodont Zone, that it is to say below the start of the Givetian defined at the base of the Polygnathus hemiansatus Zone. Therefore, the EifelianGivetian boundary is not known with precision.

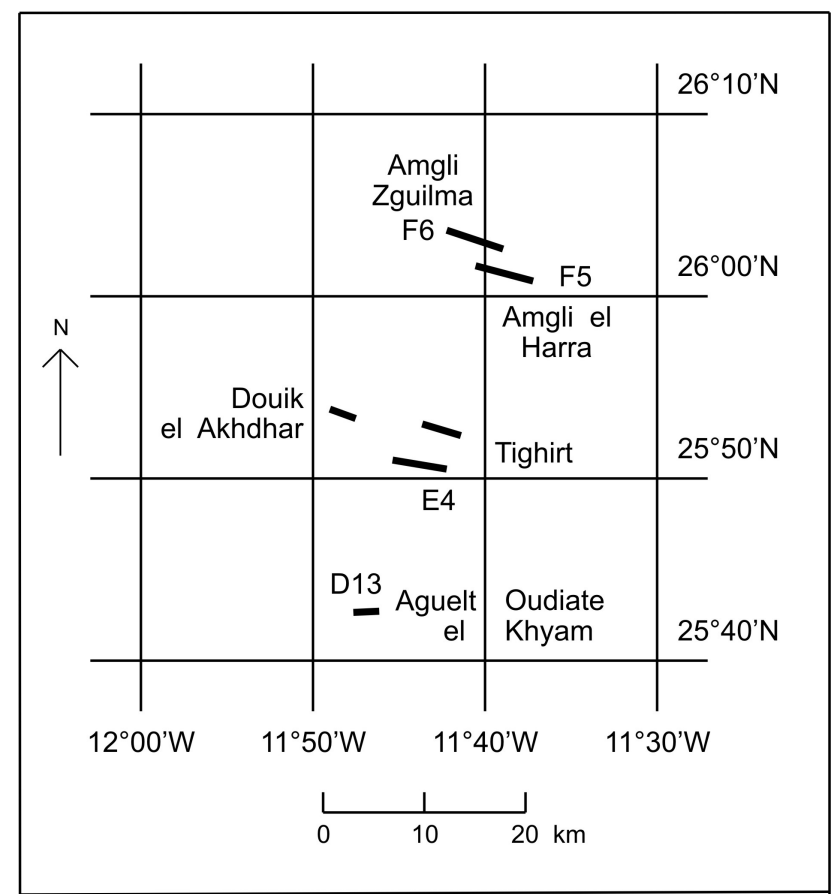

Figure 2. Location of the Givetian sections from the Zemmour investigated in this paper, after fig. 71 of Sougy (1964). This area is situated to the north of Bir Moghreim whose geographical coordinates are $25^{\circ} 13^{\prime} \mathrm{N}$ and $11^{\circ} 34^{\prime} \mathrm{W}$. 


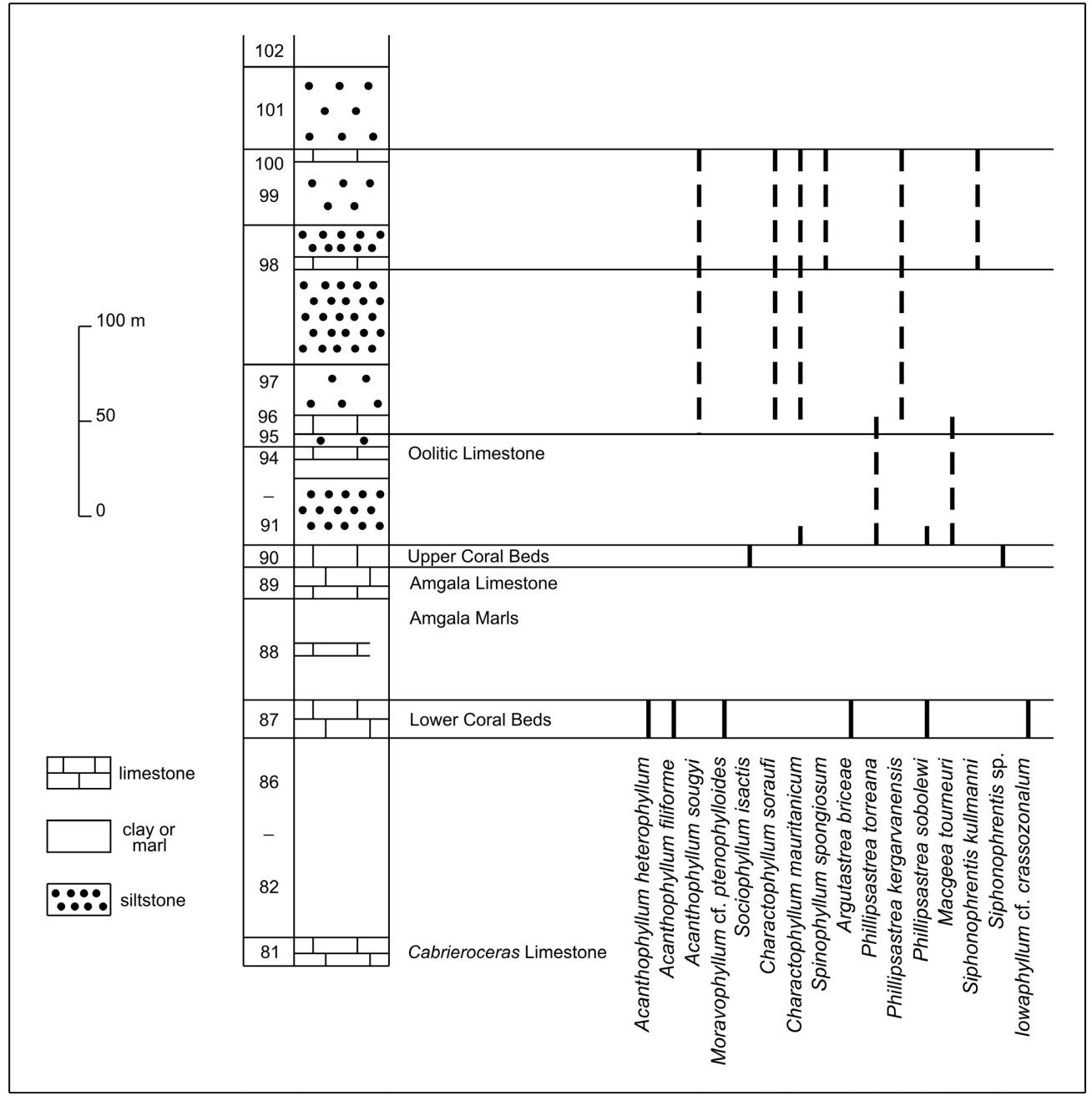

Figure 3. Schematic lithologic column for the Givetian of the Zemmour according to the detailed data provided by Sougy (1964), with the distribution of rugose corals.

The lower part of the succession between units 82 and 90 of Sougy (1964) consists of $208 \mathrm{~m}$ of marls with several intercalations of limestone. Two of these intercalations are coralliferous and named by Sougy (1964) Lower Coral Beds for unit 87 and Upper Coral Beds for unit 90. In unit 87, the following taxa have been observed:

- Argutastrea briceae (Rohart, 1988) in the section of Douik el Akhdar;

- Acanthophyllum heterophyllum (Mine-Edwards \& Haime, 1851), A. filiforme n. sp. and Moravophyllum cf. ptenophylloides Kettnerova, 1932 in section D13 of Aguelt Oudiate el Khyam;

- Phillipsastrea sobolewi and Iowaphyllum cf. crassozonalum $\mathrm{He}, 1978$ in section E4 of Tighirt.

In the latter section, only a few specimens of Sociophyllum isactis (Frech, 1886) and Siphonophrentis sp. have been identified in unit 90.

The upper part of the Givetian from the Zemmour has been investigated less precisely by Sougy (1964), in section F6 of Amgli el Harra and Amgli Zguilma. Between units 91 and 100 , there are $209 \mathrm{~m}$ of siltstones and clays with again a few intercalations of limestone. Rugose corals have been collected by Sougy (1964) a few metres above unit 90 as well as in units 96, 98 and 100. Charactophyllum mauritanicum n. sp., Phillipsastrea sobolewi, P. torreana and Macgeea tourneuri n. sp. are present at the base of unit 91. M. tourneuri and Phillipsastrea torreana have also been recorded slightly higher in sample 2392 (Fig. 4) of Sougy (1964). Samples 2396, 2398 and 2413 of this author come probably from units 96,98 or 100 whereas his sample $2381 \mathrm{C}$ and D comes probably from units 98 or 100 . For a few samples such as 2443 , there is no geographic and stratigraphic information provided by the letters and specimen labels of J. Sougy. Despite this imprecision, the diversified rugose coral fauna of units 96, 98 and 100 is represented by Acanthophyllum sougyi n. sp., Charactophyllum soraufi n. sp., C. mauritanicum, Spinophyllum spongiosum (Schlüter, 1889), Phillipsastrea kergarvanensis and Siphonophrentis kullmanni (Birenheide, 1978).

\begin{tabular}{|c|c|c|c|c|c|c|}
\hline $\begin{array}{c}\text { CORALLIFEROUS } \\
\text { UNITS }\end{array}$ & $\begin{array}{l}\text { SECTION OF } \\
\quad \text { DOUIK } \\
\text { EL AKHDHAR }\end{array}$ & $\begin{array}{l}\text { SECTION D13 OF } \\
\text { AGUELT OUDIATE } \\
\text { EL KHYAM }\end{array}$ & $\begin{array}{l}\text { SECTION E4 } \\
\text { OF TIGHIRT }\end{array}$ & \multicolumn{3}{|c|}{$\begin{array}{l}\text { SECTION F6 OF AMGLI } \\
\text { EL HARRA AND AMGLI } \\
\text { ZGUILMA }\end{array}$} \\
\hline 100 & & & & \multirow{2}{*}{$2381 C$ and $D$} & & \\
\hline 98 & & & & & 2396 & \\
\hline 96 & & & & & 2392 & $\downarrow$ \\
\hline $\begin{array}{c}\text { A few } m \text { above } \\
90\end{array}$ & & & & & $\begin{array}{l}2391 \\
2389\end{array}$ & \\
\hline $\begin{array}{c}90 \\
\text { Upper Coral Beds }\end{array}$ & & & $5552 \mathrm{~K}$ & & & \\
\hline $\begin{array}{c}87 \\
\text { Lower Coral Beds }\end{array}$ & 417 & 5544B, F and G & $\begin{array}{l}5547 \mathrm{D} \\
5314\end{array}$ & & & \\
\hline
\end{tabular}

Figure 4. Relations between the coralliferous units, sections and samples of Sougy (1964) from the Givetian of the Zemmour, investigated herein and by Coen-Aubert (2013) 
At the top of section F6 f Amgli el Harra and Amgli Zguilma, unit 100 of Sougy (1964) is overlain first by $43 \mathrm{~m}$ of clays and siltstones with brachiopods (unit 101) and then by $100 \mathrm{~m}$ of silty clays with rare fossils (unit 102). No appropriate arguments are available in these deposits to recognize the Givetian-Frasnian boundary.

As noted by Coen-Aubert (2013), the Givetian succession of the Zemmour has been compared by Dumestre \& Illing (1967) and Wendt \& Kaufmann (2006) with that situated about $100 \mathrm{~km}$ to the north, close to Smara in the northern part of Western Sahara. The correlations proposed by these authors are based on several levels of coralliferous limestone as well as on the key bed of oolitic limestone occurring at the top of unit 94 (Fig. 3) of Sougy (1964). According to Wendt \& Kaufmann (2006), the lower and upper boundaries of the Givetian are also not clearly defined in Western Sahara.

\section{Systematic Palaeontology}

The types of the new species and the figured specimens are stored in the Collection of Palaeontology of the Institut royal des Sciences naturelles de Belgique at Brussels (IRScNB). All the material investigated herein was collected by J. Sougy in the Zemmour during the early Sixties.

Family Ptenophyllidae Wedekind, 1923

\section{Genus Acanthophyllum Dybowski, 1873}

Type species. By subsequent designation of Schlüter (1889, p. 38), Cyathophyllum heterophyllum Milne-Edwards \& Haime, 1851.

Diagnosis. Large solitary rugose corals. Septa of two orders, rarely discontinuous at the periphery, thin to more or less dilated throughout their length. Major septa, sometimes thicker in the outer or in the inner part of the dissepimentarium, carinate in the tabularium and reaching usually the axis of the corallum. Minor septa traversing the entire dissepimentarium. Wide dissepimentarium composed of numerous rows of inclined dissepiments which are occasionally subhorizontal at the periphery. Tabulae incomplete and closely spaced, forming concave floors. 1851)

Acanthophyllum heterophyllum (Milne-Edwards \& Haime, (Plate 1A-B)

v*1851 Cyathophyllum heterophyllum; Milne-Edwards \& Haime: 367 , pl. 10, figs 1, 1a-b.

v 1997 Acanthophyllum heterophyllum (Milne-Edwards \& Haime, 1851); Coen-Aubert:11, pl. 1, figs 1-4, pl. 2, figs 5-7.

non 2005 Acanthophyllum heterophyllum (Milne-Edwards \& Haime); Jin: 118, pl. 17, figs 1-8.

v 2011 Acanthophyllum heterophyllum (Milne-Edwards \& Haime, 1851); Coen-Aubert: 36, pl. 2, fig. 6.

Remarks. More complete lists of synonymy with the references before 1997 and 2011 have been provided by CoenAubert $(1997,2011)$.

Holotype. Specimen Z47a or MNHN LP S 11670 from the collection Milne-Edwards stored in the Laboratory of Palaeontology, Muséum National d'Histoire naturelle in Paris, France. Devonian of the Eifel Hills in Germany; locality details mentioned by Birenheide (1961) are unsatisfactory as he thought that the type of the species was probably lost. Pl. 10, figs 1, 1a and 1b in Milne-Edwards \& Haime (1851) and pl. 1, figs 1-2 in Coen-Aubert (1997).

Material. 1 specimen with 2 thin sections: Zemmour 5544B 1. 9160-I.

Diagnosis. A species of Acanthophyllum with 70 to 90 septa at a diameter of $20 \mathrm{~mm}$ to $42 \mathrm{~mm}$. Major septa strongly dilated in the inner dissepimentarium. Dissepiments often arranged in horizontal layers at the periphery.

Description. The only corallum available is $8 \mathrm{~cm}$ high and is cylindrical with longitudinal ribs. The outer wall is not preserved.

The septa are non-carinate and strongly dilated throughout their length. The major ones are thicker in the dissepimentarium than the minor ones. Locally, both orders of septa may be divided longitudinally into two parts, at the periphery where there are a few dissepiments like abutments. The major septa bear vepreculae in the tabularium and reach its centre where a few fragments of them are also present. The minor septa traverse the entire and wide dissepimentarium.

The dissepimentarium consists of 19 to 26 rows of dissepiments which are arranged in horizontal layers in its outer part and inclined in its inner part. Some spots of stereoplasma occur in the dissepimentarium. The tabulae are closely spaced and vesicular; they are disrupted by axial ends of thick major septa with vepreculae.

There are 86 septa for a diameter of $32 \mathrm{~mm}$ to $43 \mathrm{~mm}$ whereas the width of the tabularium measures $14.5 \mathrm{~mm}$ to 17 $\mathrm{mm}$.

Discussion. The Mauritanian specimen is typical of the species Acanthophyllum heterophyllum though its major septa are rather strongly dilated in the main part of the dissepimentarium. The Emsian material of Yunnan in China illustrated by Jin (2005) is different as it is characterized by slightly smaller coralla with all their septa thickened in the dissepimentarium and locally a peripheral stereozone.

Distribution. The Mauritanian specimen comes from the lower part of the Givetian in the Zemmour. Acanthophyllum heterophyllum is widely distributed in the Eifelian and the Lower Givetian of the Eifel Hills in Germany, in the Upper Eifelian and the Lower Givetian from the south side of the Dinant Synclinorium in Belgium and the North of France as well as from the Ma'der in Morocco. It is also known in the Upper Emsian of the Southeastern Armorican Massif in France and in the Lower Eifelian of the Holy Cross Mountains in Poland.

\section{Acanthophyllum filiforme $\mathbf{n}$. sp.}

(Plate 1C-D; Plate 2F-G)

Derivation of name. From filiformis, $e($ Latin $)=$ threadlike, referring to the thin septa of the species.

Holotype. IRScNB a13143 (= Plate 1C-D). Specimen 5544B 1. 9160-II collected during the early Sixties by J. Sougy in the Zemmour, Mauritania.

Type locality and horizon. Sample 5544 collected at the top of section D13 described by Sougy (1964) at Aguelt Oudiate el Khyam, in the Zemmour, Mauritania. Unit 87 named Lower Coral Beds by Sougy (1964), lower part of the Givetian.

Material. 3 specimens with 6 thin sections: Zemmour 5544B 1. 9160-II and 1. 9163-I; Zemmour 5544F 1. 9168-II.

Diagnosis. A species of Acanthophyllum with 74 to 86 septa at a diameter of $24 \mathrm{~mm}$ to $44 \mathrm{~mm}$. Septa thin throughout their length. Wide dissepimentarium with numerous dissepiments often arranged in horizontal layers at the periphery.

Description. The material consists of conical and ceratoid coralla with longitudinal ribs and growth lines whose height varies between $4 \mathrm{~cm}$ and $8.5 \mathrm{~cm}$. In one of them, an excavated calice is bordered by a flat platform whereas another one belongs to a young stage. The outer wall is very rarely preserved.

The septa are non-carinate and thin throughout their length. Occasionally, the major septa are weakly dilated in the inner part of the dissepimentarium. They reach the axis of the 
corallum where they are slightly twisted. In the centre of the tabularium, a few fragments of them, a pseudofossula, a little stereoplasma or a few vepreculae are locally observed. The minor septa traverse the entire and wide dissepimentarium; they are sometimes discontinuous at the periphery in the young stage.

In adult coralla, the dissepimentarium consists of 22 to 30 rows of globose dissepiments which are arranged in horizontal layers in its outer part and inclined in its inner part. There are only 12 to 14 rows of inclined dissepiments at the tip of the young corallum. The tabulae are incomplete or vesicular with an overall concave pattern. They are disrupted by axial ends of septa often bearing vepreculae. A little stereoplasma is present close to the base of the corallum.

In the adult specimens, there are 86 septa for a diameter of $35 \mathrm{~mm}$ to $44 \mathrm{~mm}$ whereas the width of the tabularium measures $8.5 \mathrm{~mm}$ to $10 \mathrm{~mm}$. In the young stage, there are only 74 septa for a diameter of $20 \mathrm{~mm}$ to $26 \mathrm{~mm}$ and the tabularium is $6.5 \mathrm{~mm}$ to $7 \mathrm{~mm}$ wide.

Discussion. By its slender septa, Acanthophyllum filiforme is related to $A$. vermiculare (Goldfuss, 1826) from the Upper Eifelian and the Lower Givetian of the Eifel Hills in Germany. However, the latter species is separated from the former by slightly smaller coralla, by mostly inclined dissepiments and by septa weakly dilated throughout their length though they are sometimes thinner at the periphery. The abundant Belgian material of $A$. vermiculare close to the EifelianGivetian boundary has been investigated by Coen-Aubert (1997). As discussed by Schröder \& Kazmierczak (1999) and Coen-Aubert (2011), A. torquatum (Schlüter, 1884) from the Eifelian of the Eifel Hills is probably conspecific with A. vermiculare. Thin septa characterize also Grypophyllum mirabile Birenheide, 1972 renamed G. frechi Birenheide, 1974. But this taxon from the Upper Eifelian of the Eifel Hills is distinguished from Acanthophyllum filiforme by septa often discontinuous at the periphery and by its tabularium much better separated from the dissepimentarium. Grypophyllum frechi has also been described by Birenheide (1978).

Distribution. The species is only known in the lower part of the Givetian from the Zemmour in Mauritania.

Acanthophyllum sougyi $\mathrm{n}$. sp.

(Plate 1G-H; Plate 2D-E; Plate 4F)

Derivation of name. The species is dedicated to Jean Sougy, a distinguished French geologist who collected during the Sixties all the material from the Zemmour in Mauritania available for this study.

Holotype. IRScNB a13145 (= Plate 1G-H). Specimen 2381D 1. 9144-I collected during the early Sixties by J. Sougy in the Zemmour, Mauritania.

Type locality and horizon. Sample 2381 collected close to the section F6 of Amgli el Harra and Amgli Zguilma described by Sougy (1964) in the Zemmour, Mauritania. Probably unit 98 or 100 of Sougy (1964), Middle to Upper Givetian.

Material. 6 specimens with 16 thin sections: Zemmour 2381D 1. 9144-I and IX; Zemmour 2396 1. 7167-II; Zemmour 2413 1. 7170-I and IV; Zemmour 2443 1. 7192-V.

Diagnosis. A species of Acanthophyllum with 76 to 88 septa at a diameter of $27 \mathrm{~mm}$ to $44 \mathrm{~mm}$. Major septa reaching the axis of the corallum with some stereoplasmic thickenings in the tabularium. Tabulae mostly vesicular.

Description. The material consists of conical and sometimes cylindrical coralla with longitudinal ribs whose height varies between $3 \mathrm{~cm}$ and $7 \mathrm{~cm}$. One specimen has a more or less triangular transverse section whereas in two others, an excavated calice is bordered by a broad peripheral platform. The outer wall is very locally preserved in some coralla.
The septa are non-carinate and strongly dilated throughout their length. They may be slender at the periphery where they are rarely discontinuous and where there are some dissepiments like abutments in a few specimens. The major septa are occasionally thicker in the dissepimentarium than the minor ones. In rare cases, they are partly thinner in the tabularium. More or less stereoplasma is locally present on a layer of dissepiments, at the inner border of the dissepimentarium and within the tabularium, especially at its centre. In the young stages, the septa are much dilated and often contiguous.

The major septa reach commonly the axis of the coralla; their axial ends are sometimes rhopaloid, discontinuous, slightly twisted, united laterally or bearing rare carinae. The minor septa traverse the entire and wide dissepimentarium; they are rarely shorter or hardly projecting into the tabularium where they may be contratingent.

The dissepimentarium consists of 16 to 21 or only 9 rows of inclined dissepiments which are frequently horizontal at the periphery. Some spots of stereoplasma with contiguous septal trabeculae occur in the dissepimentarium. The tabulae are closing spaced and usually vesicular with a weak concave pattern. They are affected by local stereoplasmic thickenings and they are disrupted by axial ends of thick and discontinuous major septa with rare carinae.

There are 74 to 94 septa per corallum. The diameter of the corallum ranges from $27 \mathrm{~mm}$ to $51 \mathrm{~mm}$ in the adult specimens and from $19 \mathrm{~mm}$ to $20 \mathrm{~mm}$ in the young stages. The width of the tabularium varies between $10.5 \mathrm{~mm}$ and $20 \mathrm{~mm}$.

Discussion. Acanthophyllum sougyi is related to $A$. heterophyllum by its quantitative data, by the thickness and the length of the septa and by numerous dissepiments often arranged in horizontal layers at the periphery. It is different in having major and minor septa nearly equally dilated throughout the dissepimentarium, some stereoplasmic thickenings in the tabularium and more vesicular tabulae. Such stereoplasmic thickenings affect the tabularium of $A$. radiatum (Wedekind, 1924) and $A$. filosum (Wedekind, 1923) from the Eifelian of the Eifel Hills in Germany. They are weak in A. filosum and more strongly developed in A. radiatum. However, these two taxa have rather thin septa at the periphery as shown by the illustrations of Birenheide (1961, 1978). A. sougyi resembles more in transverse section the corallum from the Eifelian of Northwest Turkey assigned to A. cf. filosum by Birenheide \& Kaya (1987); but this specimen is distinguished in longitudinal section by wider incomplete tabulae and fewer inclined dissepiments. Finally, A. sougyi has some affinities with A. baculoides (Pocta, 1902) from the Pragian of Bohemia in the Czech Republic, which has been revised by Oliver \& Galle (1971). In the lectotype selected by these authors, the septa are more or less discontinuous at the periphery whereas in the rest of their material, all the septa are much thicker throughout the dissepimentarium.

Distribution. The species is only known in the Middle to Upper Givetian from the Zemmour in Mauritania.

Family Cyathophyllidae Dana, 1846

\section{Genus Moravophyllum Kettnerova, 1932}

Type species. By original designation, Moravophyllum ptenophylloides Kettnerova, 1932.

Diagnosis. Large solitary rugose corals. Septa of two orders, non-carinate and thin in the dissepimentarium. Major septa more or less thickened within the tabularium, up to rather late growth stages. Major septa reaching the axis of the corallum or leaving an open space in the centre of the tabularium. Minor septa traversing the entire dissepimentarium. Narrow dissepimentarium composed of globose dissepiments arranged in horizontal layers in its outer part and inclined towards the axis of the corallum in its inner part. Broad tabularium with usually incomplete tabulae. 


\section{Moravophyllum cf. ptenophylloides Kettnerova, 1932 (Plate 2B-C)}

cf. 1932 Moravophyllum ptenophylloides n. sp.; Kettnerova : 29, figs 8-12.

cf. 1932 Ptenophyllum celechovicense n. sp.; Kettnerova: 24, figs 3-5, pl. 3, figs 7-8. 6-7.

cf. 1932 Ptenophyllum irregulare n. sp.; Kettnerova: 26, figs

cf. 1978 Moravophyllum ptenophylloides Kettnerova 1932; Birenheide: 82, fig. 44.

cf. 1981 Moravophyllum ptenophylloides; Hill: F303, figs 197, 1a-c.

? 2005 Moravophyllum ptenophylloides Kettnerova; Jin: 130, pl. 20, figs 9-12, pl. 21, figs 1-7.

Holotype. Specimen PrFUK $\mathrm{N}^{\circ} 19$ from the Remes collection stored in the Geological Institute of the Charles University at Prague, Czech Republic. Lower Givetian Celechovice Limestone at Celechovice in Moravia, Czech Republic according to Galle (2007). Figs 8-12 in Kettnerova (1932), fig. 44 in Birenheide (1978) and figs 197, 1a-c in Hill (1981).

Material. 1 specimen with 2 thin sections: Zemmour 5544G 1. 9166.

Diagnosis. A species of Moravophyllum with 90 to 124 septa at a diameter of $25 \mathrm{~mm}$ to $50 \mathrm{~mm}$. Major septa reaching the axis of the corallum and thin to slightly thicker within the tabularium. Long minor septa.

Description. The only corallum available is $8.5 \mathrm{~cm}$ high and is ceratoid with longitudinal ribs and a deep calice. The transverse section is faintly elliptical whereas the outer wall is not preserved.

The septa are non-carinate or bear rare small nodes at the periphery. They are thin or locally slightly dilated in the dissepimentarium. They are frequently thicker at its inner border or within the tabularium. The major septa leave a small open space in the centre of the corallum where there are a few fragments of them; one pseudofossula is also present. The minor septa are traversing all or nearly all the dissepimentarium and they are rather often contratingent; they are rarely shorter or discontinuous at their inner ends.

The dissepimentarium consists of 10 rows of globose dissepiments which are arranged in horizontal layers in its outer part and inclined in its inner part. The tabulae are closely spaced, incomplete and intersecting laterally. At the base of the corallum, there are thickened and more or less contiguous septa which become discontinuous upwards, in later ontogenetic stages and finally disappear.

There are 118 septa for a diameter of $38 \mathrm{~mm}$ to $60 \mathrm{~mm}$ whereas the width of the tabularium measures $18 \mathrm{~mm}$ to 21 $\mathrm{mm}$.

Discussion. By comparing the descriptions and illustrations of Moravophyllum ptenophylloides, M. celechovicense (Kettnerova, 1932) and M. irregulare (Kettnerova, 1932) given by Kettnerova (1932), it is clear that these three species from the Lower Givetian of Celechovice in Moravia are synonymous. For Birenheide (1978), M. tenuiseptatum Kettnerova, 1932 from the same locality belongs also to this taxon; however, it is not so well known as its longitudinal section has not been figured by Kettnerova (1932). Additionally, Birenheide (1987) had already assigned M. irregulare to the genus Moravophyllum Kettnerova, 1932.

The Mauritanian specimen differs from M. ptenophylloides and its two synonyms by a small open space in the centre of the tabularium and occasionally shorter minor septa which do not traverse systematically the entire dissepimentarium. The abundant material of Jin (2005) does not show any septal thickening within the tabularium. Moravophyllum oliveri Birenheide, 1987 from the Upper Eifelian Freilingen
Formation of the Eifel Hills in Germany is very close to $M$. ptenophylloides; however, the former species is separated from the latter by its septa which are slightly fewer and much more dilated throughout their length, during the young ontogenetic stages. The corallum also from the Upper Eifelian of the Eifel Hills identified as $M$. cf. oliveri by Schröder (1995) resembles more the Mauritanian specimen.

Distribution. Besides the questionable specimen from the lower part of the Givetian in the Zemmour (Mauritania), Moravophyllum ptenophylloides is only known in the Lower Givetian from Moravia in the Czech Republic. It may be present in the Lower to Middle Devonian from Yunnan in China.

Family Stringophyllidae Wedekind, 1922

\section{Genus Sociophyllum Birenheide, 1962}

1962 Stringophyllum (Sociophyllum) Birenheide: 53. 1978 Parasociophyllum Kong in Kong \& Huang: 111. 1981 Stringophyllum (Gaofengophyllum) Kong: 55.

Type species. By original designation, Spongophyllum elongatum Schlüter, 1881.

Diagnosis. Fasciculate rugose corals. Septa of two orders, rather thick and consisting of coarse monacanthine trabeculae. Septa sometimes continuous from the wall to the axis of the corallites, but more often disrupted at the periphery by presepiments. Major septa bilaterally arranged and reaching or not the centre of the tabularium where they are occasionally breaking up into isolated trabeculae. Minor septa lacking or poorly developed. Dissepimentarium composed of a few rows of elongate dissepiments. Tabulae complete or incomplete, normally concave.

\section{Sociophyllum isactis (Frech, 1886)}

(Plate 1E-F)

* p. 1886 Cyathophyllum isactis n. sp.; Frech: 75, pl. 1, fig. 7, pl. 2, figs 13-18 (non fig. 19).

1911 Cyathophyllum isactis Frech; Frech: 52, pl. 8, fig. 5.

1925 Grypophyllum isactis Frech; Wedekind: 14, 16-17, pl. 4 , figs $12-14$.

v 1958 Stringophyllum? isactis (Frech, 1886); Engel \& Von Schouppé: 90, figs 13-14, pl. 8, figs 7-8.

1974 Neospongophyllum isactis (Frech); Song: 167, pl. 78, fig. 5.

? 1998 Stringophyllum cf. isactis Frech (1886); Birenheide, 179, pl. 10, fig. 4.

v 1999 Sociophyllum isactis (Frech, 1886); Coen-Aubert: 33 , pl. 1 figs $8-10$, pl. 2, figs 10-12, pl. 3, figs 5-10.

v 2000 Sociophyllum isactis (Frech, 1886); Coen-Aubert: pl. 3, fig. 10 .

2002 Sociophyllum isactis; Coen-Aubert: 11.

2005a Stringophyllum isactis (Frech, 1886); Schröder: 104, pl. 10, figs 5-6.

v 2016 Sociophyllum isactis (Frech, 1886); Coen-Aubert in Brice: figs 110, H-I.

non 2017 Parasociophyllum isactis (Frech), 1886; Liao \& Ma: 73, figs 4, 1-4.

Remark. A complete list of synonymy for the references before 1998 has been provided by Coen-Aubert (1999).

Lectotype. Specimen SMF WDKD 2584 chosen by Wedekind (1925, p. 16) and stored in the Forschungsinstitut Senckenberg at Frankfurt am Main, Germany. Givetian Büchel Formation at Schladetal, close to Bergisch Gladbach in the Bergisches Land, Germany. P1. 2, fig. 15 in Frech (1886) and pl. 4, fig. 12 in Wedekind (1925). For a long time, the lectotype was presumed lost and a neotype was selected by Engel \& Von Schouppé (1958). However Birenheide (1998, p. 179) claimed that he has found again the lectotype of Wedekind (1925). 
Material. 1 specimen with 2 thin sections: Zemmour 5552K-MAU45.

Diagnosis. A species of Sociophyllum with 25 to 30 major septa at a diameter of $8 \mathrm{~mm}$ to $13 \mathrm{~mm}$. Major septa commonly continuous from the outer wall to the axis of the corallite. Minor septa lacking.

Description. The only corallite available, which is $3 \mathrm{~cm}$ high, is cylindrical with longitudinal ribs. The outer wall is not preserved.

The non-carinate septa are dilated throughout their length though they may be progressively less thick within the tabularium. The septa are locally discontinuous at the periphery with a few lonsdaleoid dissepiments. The major septa more or less reach the axis of the corallite where there are a few trabeculae; their axial ends are sometimes rhopaloid. The minor septa are lacking or represented by rare small spines. Some layers of dissepiments are occasionally affected by a weak stereoplasmic thickening.

The dissepimentarium consists of 1 to 3 rows of large inclined dissepiments. The more or less incomplete tabulae with a concave pattern are disrupted by coarse trabeculae and fragments of septa.

There are 34 major septa for a diameter of $10 \mathrm{~mm}$ to $14 \mathrm{~mm}$ whereas the width of the tabularium measures $8 \mathrm{~mm}$ to $8.2 \mathrm{~mm}$.

Discussion. Sociophyllum isactis is the type species of Parasociophyllum Kong in Kong \& Huang (1978). However, the Chinese genus is based on the specimen of $S$. isactis figured by Frech (1911) and coming from the Givetian of Tien Shan in China. Several authors such as Hill (1981, p. F248) consider that this corallite is conspecific with the Givetian German material of Frech (1886). As $S$. isactis is mostly represented by fragments of slender cylindrical corallites with some lateral buds suggesting a fasciculate growth form, Parasociophyllum is here placed in synonymy with Sociophyllum Birenheide, 1962. Coen-Aubert (2000) has indeed figured a fasciculate colony of Sociophyllum isactis from the Givetian of Belgium.

Though the Mauritanian specimen of $S$. isactis is characterized by some discontinuity of the septa at the periphery, it falls within the wide variability of the species illustrated in the Givetian of Belgium and Germany (CoenAubert, 1999; Wedekind, 1925). Concerning the list of synonymy, it is difficult to identify the fragmentary longitudinal section assigned to $S$. cf. isactis by Birenheide (1998) and occurring in the Givetian of the Viersen 1001 borehole from Northwest Germany. The Givetian material from Northeast Yunnan in China figured by Liao \& Ma (2017) is variable, but typically fasciculate. More particularly, it has horizontal layers of small dissepiments and sometimes mesa-shaped tabulae. Therefore, it does not belong to the genus Sociophyllum.

Distribution. Besides the Mauritanian specimen from the Givetian of the Zemmour, Sociophyllum isactis is widely distributed in the Givetian of the Old World Realm. In Belgium, the species is present at the top of the Lower Givetian, mainly on the south side of the Dinant Synclinorium. In Germany, it comes from the Givetian Büchel Formation in the Bergisches Land and from the Givetian of Sötenich in the Eifel Hills without more precision. S. isactis also occurs in the Givetian of Moravia in the Czech Republic, from the Russian Platform and the Urals in Russia, from Tien Shan, Guizhou and Yunnan in China and from New South Wales and North Queensland in Australia.

Family Disphyllidae Hill, 1939

\section{Genus Charactophyllum Simpson, 1900}

Type species. By original designation, Campophyllum nanum Hall \& Whitfield, 1873.

Diagnosis. Solitary rugose corals. Septa of two orders, non-carinate to faintly carinate and more or less dilated in the dissepimentarium. Major septa commonly with weak to strong additional dilation within the tabularium, in some or all stages of corallite growth. Major septa reaching the axis of the tabularium or leaving an open space in the centre of the tabularium. Minor septa traversing the entire dissepimentarium. Dissepimentarium composed of several rows of globose dissepiments, often arranged in horizontal layers in its outer part and inclined towards the axis of the corallum in its inner part. Tabulae usually incomplete or compound.

Charactophyllum soraufi $\mathrm{n}$. sp.

(Plate 2A; Plate 3E-H; Plate 5F-G)

Derivation of name. The species is dedicated to James Sorauf, a distinguished American specialist of Devonian rugose corals.

Holotype. IRScNB a13150 (= Plate 3E-F). Specimen 2381D-MAU34 collected during the early Sixties by J. Sougy in the Zemmour, Mauritania.

Type locality and horizon. Sample 2381 collected close to the section F6 of Amgli el Harra and Amgli Zguilma described by Sougy (1964) in the Zemmour, Mauritania. Probably unit 98 or 100 of Sougy (1964), Middle to Upper Givetian.

Material. 18 specimens with 31 thin sections : Zemmour 2381D-MAU34, MAU35, MAU36, MAU37, MAU38, MAU39, MAU41, MAU42, MAU79, MAU82, 1. 9144-II, IV, VI and X ; Zemmour 2398-MAU30, 1. 7169-I and IV, 1. 8195VII.

Diagnosis. A species of Charactophyllum with 62 to 74 septa at a diameter of $15 \mathrm{~mm}$ to $25 \mathrm{~mm}$. Septa rarely carinate and slightly dilated in the dissepimentarium. Major and minor septa more or less long. Rather wide dissepimentarium.

Description. The material consists of conical, trochoid and ceratoid coralla with longitudinal ribs whose height varies between $1.5 \mathrm{~cm}$ and $6 \mathrm{~cm}$. In some specimens, an excavated calice is bordered by a flat peripheral platform whereas a few others are affected by rejuvenescence. The outer wall is rarely preserved and the coralla may be abraded at the periphery.

The septa are non-carinate or bear a few spinose, knobbly and even yardarm carinae in the outer dissepimentarium of some specimens. The septa are slightly dilated in the dissepimentarium with occasionally the major ones thicker than the minor ones. They are sometimes thinner at the periphery or in the tabularium. However, the septa are often dilated throughout their length, thicker or less thick in the tabularium. In a few coralla, a stereoplasmic thickening is present within the dissepimentarium whereas a more or less continuous inner wall occurs at the border of the tabularium, in some juvenile transverse sections.

The major septa reach the axis of the corallum or leave an open space in the centre of the tabularium. Their axial ends are sometimes rhopaloid, forming pseudofossulae or breaking into fragments. In a few specimens, some stereoplasma is present in the tabularium, between the septa or at its centre. The minor septa traverse the entire dissepimentarium. They are occasionally shorter, contratingent, discontinuous especially at their inner ends or hardly projecting into the tabularium.

The dissepimentarium consists of 3 to 12 or even 17 rows of small globose dissepiments which are arranged in horizontal layers in its outer part and inclined in its inner part. Some spots of coarse and usually contiguous septal trabeculae occur in the dissepimentarium whereas an inner stereozone may be present at the base of the corallum and in the longitudinal sections of young stages. The tabulae are incomplete and intersecting laterally, often with a flattopped or horizontal axial part which is locally affected by a stereoplasmic thickening; the tabulae are rarely concave or horizontal.

There are 60 to 80 septa per corallum. The diameter of the corallum ranges from $13.5 \mathrm{~mm}$ to $27 \mathrm{~mm}$. The width of the 
tabularium varies between $8.2 \mathrm{~mm}$ and $13.5 \mathrm{~mm}$.

Discussion. Charactophyllum Simpson, 1900 and its type species C. nanum (Hall \& Whitfield, 1873) from the Upper Frasnian of Iowa in USA have been well revised by Sorauf (1998) and McLean (2014). The latter author restricted the genus to a few Frasnian species and to $C$. burdekinense Zhen \& Jell, 1996 from the Lower Givetian of North Queensland in Australia. Qualitatively, C. burdekinense which shows notably septa more or less thick in the tabularium, looks similar to $C$. soraufi, but differs from it by smaller septal number and diameter of the corallum. According to McLean (2014), Spinophyllum complicatum (Wang, 1948) from the Givetian of Yunnan in China could possibly be referred to Charactophyllum. However, this species is more carinate than C. soraufi. As described by Soshkina (1952, p. 68) and Sytova et al. (1974, p. 37), C. armenicum (Soshkina, 1952) from the Givetian of Armenia resembles the new species though it is characterized by a narrower dissepimentarium, more septa and larger coralla. On the contrary and as mentioned by McLean (2014), the specimen figured by Soshkina et al. (1962, pl. 6, fig. 5) as C. armenicum does not belong to the same genus and species as it has carinate and weakly dilated septa.

At first view, there are some affinities between $C$. soraufi and Spinophyllum blacourti (Rohart, 1988) from the Givetian of the Boulonnais in France. However, the latter is easily separated from Charactophyllum by its septa becoming systematically thin in the tabularium and is also well known in the Givetian of Belgium (Coen-Aubert, 2002).

Distribution. The species is only known in the Middle to Upper Givetian from the Zemmour in Mauritania.

Charactophyllum mauritanicum n. sp.

(Plate 3A-D; Plate 4A-C)

Derivation of name. From mauritanicus, a, um (Latin) referring to the country where the new species has been collected.

Holotype. IRScNB a13154 (= Plate 3A-B). Specimen 2398 1. 7168-III collected during the early Sixties by J. Sougy in the Zemmour, Mauritania.

Type horizon and locality. Sample 2398 collected in the section F6 of Amgli el Harra and Amgli Zguilma described by Sougy (1964) in the Zemmour, Mauritania. Probably between units 96 and 100 of Sougy (1964), Middle to Upper Givetian.

Material. 10 specimens with 19 thin sections: Zemmour 2389-MAU21 and MAU25; Zemmour 2398 1. 7168-I, II, III, IV and VII, 1. 7169-II, III and V.

Diagnosis. A species of Charactophyllum with 70 to 80 septa at a diameter of $20 \mathrm{~mm}$ to $30 \mathrm{~mm}$. Major septa more or less reaching the axis of the corallum and commonly very thickened in the tabularium. Incomplete tabulae intersecting laterally.

Description. The material consists of conical and ceratoid coralla whose height varies between $2 \mathrm{~cm}$ and $6 \mathrm{~cm}$; longitudinal ribs and growth lines are sometimes present. In one specimen, a weakly excavated calice is bordered by a flat peripheral platform. The coralla may be abraded at the periphery and the outer wall is locally preserved in a few of them.

The septa are non-carinate or bear a few small spinose, knobbly or even yardarm carinae. They are dilated throughout their length and they are often thicker in the tabularium. Occasionally, the major septa are more dilated in the dissepimentarium than the minor ones. A little stereoplasma may occur in the tabularium where the septa may also be thinner locally.

The major septa reach more or less the axis of the corallum and they are rarely shorter. Their axial ends are sometimes rhopaloid, curved, discontinuous or fusing to form pseudofossulae. In one specimen, a longer major septum is bent as a hook whereas in a few other ones, septa are locally broken in the dissepimentarium and the tabularium. The minor septa traverse the entire dissepimentarium; occasionally, they are slightly shorter, contratingent or hardly projecting into the tabularium.

The tip of the corallum is full of stereoplasma or of thick and contiguous septa. The dissepimentarium consists of 5 to 12 or even 18 rows of small globose dissepiments arranged in horizontal layers in its outer part and inclined in its inner part. The tabulae are incomplete and intersecting laterally; they are sometimes disrupted by axial ends of thick septa or affected by stereoplasmic thickenings.

There are 70 to 82 septa per corallum. The diameter of the corallum ranges from $17 \mathrm{~mm}$ to $32 \mathrm{~mm}$. The width of the tabularium varies between $8.7 \mathrm{~mm}$ and $14.5 \mathrm{~mm}$.

Discussion. Charactophyllum soraufi differs from $C$. mauritanicum by slightly smaller septal number and diameter of the corallum, by major septa less thickened in the tabularium and by tabulae often compound with a flat-topped axial part. Quantitatively, C. mauritanicum is similar to $C$. armenicum which is slightly more carinate and whose dissepimentarium is much narrower.

In transverse section, $C$. mauritanicum resembles Glossophyllum salmense Wedekind, 1924 and G. dohmi Wedekind, 1924 from the Eifelian of the Eifel Hills in Germany. In longitudinal section, $G$. salmense is characterized by very few dissepiments and flat-topped tabulae. As for G. dohmi, type species of Glossophyllum Wedekind, 1924, its lectotype is only represented by a few transverse sections figured among others by Birenheide (1978). So the genus Glossophyllum is inadequately known as mentioned already by Pedder (1982) and Coen-Aubert (1997). Charactophyllum mauritanicum has also some affinities with Thoulelasma yukonanum Pedder, 1984 from the Lower Emsian of the Yukon Territory in Canada. However, the latter species is distinguished from the former by fewer dissepiments and by vesicular tabulae with a convex pattern. Thoulelasma loewei Pedder, 1983 from the Upper Emsian of the Northwest Territories in Canada, type species of Thoulelasma Pedder, 1983, is much larger than Charactophyllum mauritanicum and has once more vesicular tabulae as noted by Lütte (1987) in his comparison with Glossophyllum.

Distribution. The species is only known in the Middle to Upper Givetian from the Zemmour in Mauritania.

\section{Genus Spinophyllum Wedekind, 1922}

1922 Spinophyllum Wedekind: 5.

1982 Truncicarinulum Yu \& Kuang: 253.

1983 Spongielasma Cao in Cao et al.: 74.

1988 Charisphyllum Oliver \& Sorauf: 9.

Type species. By monotypy, Campophyllum spongiosum Schlüter, 1889.

Diagnosis. Solitary rugose corals. Septa of two orders, highly and irregularly carinate in the dissepimentarium with yardarm and zigzag carinae. Septa more or less dilated in the dissepimentarium and thin in the tabularium. Major septa reaching the axis of the corallum or leaving an open space in the centre of the tabularium. Minor septa traversing the entire dissepimentarium. Dissepimentarium composed of several rows of globose dissepiments arranged in horizontal layers in its outer part and inclined towards the axis of the corallum in its inner part. Tabulae incomplete or compound.

\section{Spinophyllum spongiosum (Schlüter, 1889)} (Plate 6H-I)

V* 1889 Campophyllum spongiosum Schlüt.; Schlüter: 46. 2001a Spinophyllum cf. spongiosum (Schlüter 1889); 
Schröder: 66, pl. 1, fig. 5 .

v 2002 Spinophyllum spongiosum (Schlüter, 1889); Coen-

Aubert: 15, pl. 2, figs 11-12, pl. 3, figs 3-7.

2002 Spinophyllum spongiosum (Schlüter 1889); Schröder:

180, pl. 2, fig. 13.

v 2004 Spinophyllum spongiosum (Schlüter, 1889); Barchy

et al.: pl. 1, figs 8-9.

non 2005 Spinophyllum cf. spongiosum Schlüter; Jin: 127,

pl. 18, figs 15-19 :

2005a Spinophyllum spongiosum (Schlüter, 1889);

Schröder: 64, pl. 2, fig. 6, pl. 3, figs 2-7.

v 2007 Spinophyllum spongiosum (Schlüter, 1889); Galle: fig. 2 .

v 2016 Spinophyllum spongiosum (Schlüter, 1889); CoenAubert in Brice: fig. 110J.

Remark. A complete list of synonymy for the references before 2001 has been provided by Coen-Aubert (2002).

Lectotype. Specimen Nr 174a of the Schlüter collection chosen by Birenheide \& Lütte (1990, p. 4) and stored in the Paläontologisches Institut from the University of Bonn in Germany. Givetian Büchel Formation of the disused Büchel quarry near Herrenstruden and Bergisch Gladbach in the Bergisches Land, Germany. Pl. 3, fig. 15 in Birenheide \& Lütte (1990), pl. 2, fig. 11 in Wrzolek \& Wach (1994), pl. 2, figs 11-12 in Coen-Aubert (2002) and fig. 2 in Galle (2007).

Material. 1 specimen with 2 thin sections: Zemmour 2381D-MAU33.

Diagnosis. A species of Spinophyllum with 60 to 70 septa at a diameter of $13 \mathrm{~mm}$ to $21 \mathrm{~mm}$. Yardarm and zigzag carinae rather strong and numerous. No stereoplasmic thickening between the septa in the adult stage.

Description. The only corallum available is $3 \mathrm{~cm}$ high and is conical with longitudinal ribs; its calice is excavated and bordered by steep sides. The outer wall is not preserved.

The septa with strong yardarm carinae are dilated in the dissepimentarium and thinner in the tabularium; locally they are slender at the periphery. The major septa leave a small open space in the centre of the tabularium. The minor septa traverse the entire dissepimentarium; sometimes they are hardly projecting into the tabularium where they are contratingent

The dissepimentarium consists of 6 to 8 rows of small globose dissepiments which are arranged in horizontal layers in its outer part and inclined in its inner part. The tabulae are incomplete and intersecting laterally, occasionally with a narrow flat-topped axial part.

There are 68 septa for a diameter of $18 \mathrm{~mm}$ to $20 \mathrm{~mm}$ whereas the width of the tabularium measures $8.9 \mathrm{~mm}$ to 9.5 $\mathrm{mm}$.

Discussion. Despite its septa being rather dilated in the dissepimentarium, the Mauritanian specimen falls within the variability of Spinophyllum spongiosum. Indeed, this feature appears also in some Belgian and German coralla of the taxon such as those figured by Coen-Aubert (2002, pl. 3, fig. 7), Birenheide \& Lütte (1990, pl. 2, fig. 11, pl. 3, fig. 18) and Schröder (2002). It affects more systematically $S$. altevogti (Oliver \& Sorauf, 1988), type species of Charisphyllum Oliver \& Sorauf, 1988 from the Givetian Candas Formation of Asturias in Spain, whose holotype was reillustrated by CoenAubert (2002). Additionally, this species is more strongly carinate and slightly larger than Spinophyllum spongiosum.

Distribution. Besides the Mauritanian specimen from the Middle to the Upper Givetian of the Zemmour, Spinophyllum spongiosum is widely distributed in the Belgian and German Givetian. In Belgium, it is present at the top of the Lower Givetian, mainly on the south side of the Dinant Synclinorium. In Germany, S. spongiosum is known in the Middle Givetian from the Aachen Syncline, the Eifel Hills, the Bergisches Land and the Sauerland.

\section{Genus Argutastrea Crickmay, 1960}

Type species. By original designation, Argutastrea arguta Crickmay, 1960.

Diagnosis. Massive cerioid rugose corals. Septa of both orders, non-carinate or sometimes faintly carinate, dilated in the dissepimentarium or at least in its outer part and becoming thin in the tabularium. Major septa extending to or nearly to the axis of the corallites. Minor septa variable in length. Dissepimentarium moderately wide with commonly several series of small inclined dissepiments. Tabulae incomplete, occasionally complete or compound.

\section{Argutastrea briceae (Rohart, 1988)}

(Plate 5A-C)

* 1988 Cyathophyllum briceae sp. nov.; Rohart: 282, pl. 31, fig. 15 , pl. 36, figs $1-2$.

2011 Cyathophyllum briceae Rohart, 1988; Mistiaen et al.: 94, fig. 78 .

Holotype. Specimen GFCL 4558 stored in the Department of Geology from the Faculté Libre des Sciences at Lille, France. Banc noir quarry at Ferques, Boulonnais, France. Unit c of the Griset Member, Blacourt Formation, Lower Givetian. Pl. 36, fig. 1 in Rohart (1988)

Material. 1 specimen with 3 thin sections: Zemmour 417 1. 9137.

Diagnosis. A species of Argutastrea with 40 to 56 septa at a diameter of $15 \mathrm{~mm}$ to $25 \mathrm{~mm}$. Septa weakly carinate and slender to slightly dilated in the dissepimentarium. Septa of both orders long, the minor ones traversing the entire dissepimentarium. Numerous rows of dissepiments often arranged in horizontal layers at the periphery.

Description. The only colony available is tabular and fragmentary with an area of $10 \mathrm{~cm} \times 7 \mathrm{~cm}$ and a height of 6 $\mathrm{cm}$. The large corallites are separated by a straight wall with locally a dark median line.

The septa are non-carinate or bear a few small carinae. They are slightly dilated or rather slender in the dissepimentarium. They are often becoming thin in the tabularium. The major septa reach the axis of the corallites or leave a small open space in the centre of the tabularium where a few pseudofossulae are observed. The minor septa traverse the entire and wide dissepimentarium.

The dissepimentarium consists of 6 to 12 rows of globose dissepiments which are arranged in horizontal layers in its outer part and inclined in its inner part. The tabulae are incomplete and intersecting laterally with flat-topped axial parts.

There are 48 to 52 septa per corallite. The diameter of the corallites ranges between $12.5 \mathrm{~mm}$ and $22 \mathrm{~mm}$ or even $25 \mathrm{~mm}$. The width of the tabularium varies between $4.2 \mathrm{~mm}$ and $6 \mathrm{~mm}$.

Discussion. Argutastrea briceae was assigned by Rohart (1988) to Cyathophyllum Goldfuss, 1826 whose type species is $C$. dianthus Goldfuss, 1826 from the Lower Givetian of the Eifel Hills in Germany. As mentioned already by Rohart (1988), Argutastrea briceae is not a typical representative of Cyathophyllum which is characterized by very thin septa with strongly zigzag carinae. Cyathophyllum was revised by Birenheide (1963) and discussed by Coen-Aubert (1990) who considered Argutastrea briceae as a somewhat extreme taxon of Argutastrea. Indeed, A. briceae is characterized by poorly carinate and faintly dilated septa in the dissepimentarium. Due to its large corallites, the species has a wide dissepimentarium whose outer dissepiments are often arranged in horizontal layers. Nevertheless, Rohart (1988) also observed among his numerous colonies of $A$. briceae some weakly inclined dissepiments at the periphery. Additionally, he placed in the synonymy list of $A$. briceae the Givetian material from the Boulonnais in France identified by Smith (1945, pl. 25, figs 
1-3) as Prismatophyllum boloniense (Milne-Edwards \& Haime, 1851) and showing in longitudinal section only inclined dissepiments, which is the common situation for Argutastrea. In fact, Argutastrea briceae is closely related to A. tenuiseptata Coen-Aubert \& Lütte, 1990 from the Lower Givetian of Belgium and Germany. The latter species is separated from the former by slightly smaller septal number and diameters of the corallites and by mostly inclined dissepiments. However, in Belgian colonies of A. tenuiseptata with some large corallites, the dissepiments are locally arranged in horizontal layers at the periphery.

Despite the overall pattern of the dissepimentarium, $A$. briceae cannot be referred to Hexagonaria Gürich, 1896 whose type species is Cyathophyllum hexagonum Goldfuss, 1826 from the Frasnian of the Bergisches Land in Germany. Indeed, Hexagonaria is characterized in transverse section by spindleshaped dilated septa in the inner part of the dissepimentarium as it is mentioned among others in the diagnosis of the genus given by McLean (2010). This feature is certainly not present in the colony of Argutastrea briceae from the Zemmour. On the contrary and as noted herein, Argutastrea has septa uniformly thickened in the dissepimentarium or at least in its outer part.

Distribution. Besides the colony from the lower part of the Givetian in the Zemmour, Argutastrea briceae is only known in the Lower Givetian from the Boulonnais in France.

\section{Family Phillipsastreidae Roemer, 1883}

\section{Genus Macgeea Webster, 1889}

Type species. By subsequent designation of Fenton \& Fenton (1924, p. 54), Pachyphyllum solitarium Hall \& Whitfield, 1873.

Diagnosis. Solitary rugose corals with a deep calice and the epitheca not quite extending to the rim of the calice so that the peripheral edges of the septa are exposed distally. Septa of two orders, non-carinate or sometimes faintly carinate, more or less long and dilated in the dissepimentarium, thin in the tabularium. Dissepimentarium with one outer row of flat dissepiments, a median pipe of horseshoe dissepiments and a few inner rows of small inclined dissepiments. Symmetrical fans of rhipidacanths centred over horseshoe dissepiments. Wide tabularium with incomplete or compound tabulae. Occurrence of stereome in early corallum growth stages.

\section{Macgeea tourneuri n. sp.}

(Plate 4D-E; Plate 5D-E)

Derivation of name. The species is dedicated to Francis Tourneur, a distinguished specialist of tabulate corals and Belgian marbles.

Holotype. IRScNB a13160 (= Plate 4D-E). Specimen 2391 1. $7108-V$ collected during the early Sixties by J. Sougy in the Zemmour, Mauritania.

Type locality and horizon. Sample 2391 collected close to the section F6 of Amgli el Harra and Amgli Zguilma described by Sougy (1964) in the Zemmour, Mauritania. A few metres above unit 90 of Sougy (1964), Middle to Upper Givetian.

Material. 7 specimens with 14 thin sections: Zemmour 2391 1. 7108-I, III, IV, V and VI; Zemmour 2392 1. 7165-II and III.

Diagnosis. A species of Macgeea with 78 to 88 septa at a diameter of $19 \mathrm{~mm}$ to $31 \mathrm{~mm}$. Major septa affected by stereoplasmic thickenings within the tabularium, rather late in the ontogeny. Occurrence of few rows of inner dissepiments.

Description. The material consists of often fragmentary, conical and ceratoid coralla with some longitudinal ribs and growth lines; their height varies between $2 \mathrm{~cm}$ and $6 \mathrm{~cm}$. The coralla are usually abraded at the periphery and the outer wall is only locally preserved in one of them.

The septa are non-carinate and dilated throughout their length though they become thinner in the tabularium of a few adult specimens. More or less stereoplasma is frequently present between the septa in the tabularium where these skeletal elements are very thick and contiguous in the young stages. Locally, the septa are slender or discontinuous in the outer zone of flat dissepiments. In transverse section, the pipe of horseshoe dissepiments is occasionally coated with stereome on both sides and bordered by some inner dissepiments.

In the young stages, the major septa reach the axis of the corallum. Later in the ontogeny, the same situation is still present or the major septa leave an open space in the centre of the tabularium where are observed pseudofossulae, isolated trabeculae, discontinuous or twisted septa. The minor septa traverse all or nearly all the dissepimentarium; sometimes, they are restricted to the ring of the horseshoe dissepiments or they are hardly projecting into the tabularium where they may be contratingent.

The dissepimentarium consists of:

- one peripheral row of flat dissepiments occasionally concave or intersecting laterally, which are rarely preserved;

- one row of horseshoe dissepiments with narrow symmetrical fans of rhipidacanths centred over them;

- 0 to 4 rows of inner inclined dissepiments.

In one specimen, one or two rows of external inclined dissepiments occur between the flat and horseshoe dissepiments. The tabulae are incomplete and intersecting laterally; sometimes, they are vesicular or their axial parts are flat-topped. The tabulae may be affected by local stereoplasmic thickenings or disrupted by discontinuous and mostly thick septa especially at the base of the corallum which is nearly full of stereoplasma.

There are 78 to 88 septa per corallum; their number is restricted to 68 in a juvenile specimen. The diameter of the corallum ranges from $18 \mathrm{~mm}$ to $31 \mathrm{~mm}$, but it is only $15 \mathrm{~mm}$ or $16 \mathrm{~mm}$ in young stages. The width of the tabularium varies between $12 \mathrm{~mm}$ and $19 \mathrm{~mm}$.

Discussion. Macgeea tourneuri is a peculiar species as it is represented by rather large coralla with poorly developed inner dissepiments and stereoplasmic thickenings still present within the tabularium, in rather late growth stages. A more or less similar situation characterizes $M$. soraufi McLean, 2005 from the Middle Frasnian of the Northwest Territories in Canada. However, this taxon differs from the Mauritanian material by a slightly smaller diameter, by major septa often reaching the axis of the corallum and by stereoplasma less abundant in the young stages and mostly affecting the axial ends of the major septa later in the ontogeny. McLean (2005) compared M. soraufi with M. ponderosa Stumm, 1960 from the Middle Frasnian of New York in USA, which has been revised by Sorauf (1987). M. ponderosa is separated from $M$. tourneuri by stereome always occurring in the tabularium even of adult specimens and by less constant inner dissepiments.

Distribution. The species is only known in the Middle to Upper Givetian from the Zemmour in Mauritania.

\section{Family Siphonophrentidae Merriam, 1973}

\section{Genus Siphonophrentis O'Connell, 1914}

Type species. By original designation, Caryophyllia gigantea Lesueur, 1821 placed in synonymy with Siphonophrentis elongata (Rafinesque \& Clifford, 1820) by Stumm (1964, p. 23) and Oliver (1993, p. B26) after revision of the neotypes of both species.

Diagnosis. Large ceratoid to cylindrical rugose corals. Septa of two orders non-carinate. In the young stages, septa dilated in the two cardinal quadrants. In the adult stages, septa thin to more or less dilated throughout their length, maybe with thickened peripheral ends to form a narrow stereozone. 
Short major septa and still more reduced minor septa. Occurrence of a siphonofossula. No dissepiments. Tabulae often with a mesa-shaped pattern.

\section{Siphonophrentis kullmanni (Birenheide, 1978)} (Plate 6F-G)

* 1978 Breviphrentis kullmanni n. sp. ; Birenheide: 69, pl. 9, fig. 3 .

non 2001b Contophrentis kullmanni (Birenheide, 1978) ; Schröder: 259, fig. 2.6.

Holotype. Specimen SMF 30936 stored in the Forschungsinstitut Senckenberg at Frankfurt am Main, Germany. Road between Verdiago and Valdore in the Esla valley, Leon Province in Spain. Lower part of the Givetian Portilla Formation. Pl. 9, fig. 3 in Birenheide (1978).

Material. 1 specimen with 2 thin sections: Zemmour 2381D 1. 9144-III.

Diagnosis. A species of Siphonophrentis with 90 to 100 septa at a diameter of 30 to $40 \mathrm{~mm}$. Septa more or less dilated to thin throughout their length. Rather long major septa and shorter minor septa. No peripheral stereozone.

Description. The only corallum available, which is $5 \mathrm{~cm}$ high, is conical with longitudinal ribs and a broad excavated calice. The transverse section is elliptical whereas the outer wall is partly preserved.

The non-carinate septa are more or less dilated throughout their length and are locally affected by a dark median line; they are occasionally thinner at their axial ends. The major septa leave a wide open space in the centre of the corallum where some fragments of septa are broken. The minor septa are rather short, but always present.

The tabulae are often broken with some broad flat-topped axial parts. At the base of the corallum, the septa are thick and nearly contiguous.

There are 94 septa for a diameter of $23 \times 37 \mathrm{~mm}$.

Discussion. The Mauritanian specimen is very close to the Spanish holotype figured by Birenheide (1978) which is characterized by a circular transverse section. The Spanish corallum illustrated by Schröder (2001b) as Contophrentis kullmanni comes from the Givetian Candas Formation in Asturias and is different in having a nearly continuous peripheral stereozone. The same specimen was identified by Altevogt (1967, pl. 1, fig. 8) as Heterophrentis prolifica (Billings, 1858). This taxon was chosen as type species of the genus Metaxyphrentis Oliver, 1993 and its lectotype was revised by Oliver (1993). M. prolifica from the Eifelian of Ontario in Canada is in fact represented by coralla with long and thick septa which are commonly contiguous in a wide peripheral stereozone.

As mentioned by Schröder (2001b) and Coen-Aubert (2005), Siphonophrentis kullmanni was synonymized by Pedder (1999) with S. belgebaschika (Ivania, 1955) from the Givetian of the Gornyi Altai in Russia, which is the type species of Altaiophyllum Ivania, 1955. However, the septa of the holotype of Siphonophrentis belgebaschica refigured by Ivania (1958, pl. 1, fig. 1) are much more dilated than those of S. kullmanni.

Distribution. Besides the Mauritanian specimen which comes from the Middle to the Upper Givetian of the Zemmour, Siphonophrentis kullmanni is known in the Lower to Middle Givetian from the Leon Province in Spain.

Siphonophrentis sp.

(Plate 6C-E)

Material. 3 specimens with 5 thin sections: Zemmour 5552K-MAU43, MAU44 and 1. 9186-I.
Description. The material consists of cylindrical and ceratoid coralla whose height varies between $3.5 \mathrm{~cm}$ and 6.5 $\mathrm{cm}$. The outer wall is more or less continuous, but not very thick.

The non-carinate septa are thin or slightly dilated throughout their length. However, they may also be much thicker in the two cardinal quadrants or in all the transverse section of a rather young stage. The cardinal fossula is observed in the three specimens. The major septa leave a wide open space in the centre or the corallum where their axial ends are sometimes discontinuous or weakly rhopaloid. The minor septa are short, but always present. The tabulae are incomplete and often show a convex or more or less flat-topped axial part.

There are 66 to 76 septa for a diameter of $21 \mathrm{~mm}$ to 29 $\mathrm{mm}$.

Discussion. Based on its quantitative data and some other features, Siphonophrentis sp. is related to $S$. wangi CoenAubert, 2005 from the Upper Givetian of the Tafilalt in Morocco. Nevertheless, the latter species is separated from the Mauritanian form by shorter major septa and by minor septa which are not always developed as they appear rather late during the ontogeny; additionally, the septa of $S$. wangi may be thicker in the adult stages. There are also some similarities between Siphonophrentis sp. and S. laskovae Wrzolek, 2002 which is known in the Upper Givetian from the Holy Cross Mountains in Poland and from the Ma'der in Morocco. However, S. laskovae is characterized by greater septal number and diameter of the corallum and once more by very short major septa.

Distribution. The form has only been observed in the Givetian of the Zemmour in Mauritania.

\section{Family Endophyllidae Torley, 1933}

\section{Genus Iowaphyllum Stumm, 1949}

Type species. By original designation, Smithia johanni Hall \& Whitfield, 1873.

Diagnosis. Massive aphroid rugose corals. Non-carinate septa thin in the tabularium, more or less thick in the inner dissepimentarium and continuing across the outer dissepimentarium as dilated septal ridges or crests on the top surfaces of large presepiments arranged in horizontal layers. Major septa reaching the axis of the corallites or leaving an open space in the centre of the tabularium. Minor septa restricted to the dissepimentarium. Tabulae usually incomplete with an elevated axial part.

\section{Iowaphyllum cf. crassozonalum He, 1978}

\section{(Plate 6A-B)}

cf. 1978 Iowaphyllum crassozonalum He (sp. nov.); He: 156, pl. 78 , fig. 3 . $5 b-c$.

v 1993 Iowaphyllum sp. ; Coen-Aubert \& Lütte: 49, figs

Holotype. Specimen Scr 705 stored in the Chengdu Institute of Geological and Mineral Resources at Chengdu, Sichuan Province in China. Givetian Guanwushan Formation in the Longmenshan Mountains to the north of Chengdu City, Beichuan County, Sichuan Province in China. Pl. 78, fig. 3 in $\mathrm{He}(1978)$.

Material. 1 specimen with 2 thin sections: Zemmour 5314 1. 9112 .

Diagnosis. A species of Iowaphyllum with 54 to 66 septa at tabularial diameters of $6.5 \mathrm{~mm}$ to $8 \mathrm{~mm}$. Adjacent corallite axes $13 \mathrm{~mm}$ to $18 \mathrm{~mm}$ apart. Major septa reaching the axis of the corallites, strongly dilated and contiguous in the inner dissepimentarium. 
Description. The only colony available is tabular with an area of $17 \mathrm{~cm} \times 9 \mathrm{~cm}$ and a height of $9 \mathrm{~cm}$.

The septa are continuous in the inner dissepimentarium and in the tabularium. They are very thick and often contiguous in the inner dissepimentarium. The major septa are much less dilated in the tabularium and reach the axis of the corallites; their axial ends may be rhopaloid, fusing to form pseudofossulae or bearing a few spinose carinae. The minor septa are restricted to the inner dissepimentarium and they barely project into the tabularium where they are sometimes contratingent. Outside the inner dissepimentaria, the corallites are separated by large presepiments where incomplete rings of stereoplasmic thickenings are developed, consisting of more or less short segments of thick septa.

In longitudinal section, the presepiments are arranged in horizontal layers alternating with thin zones of stereoplasmic thickenings characterized by some spines. The dissepiments are only inclined at the border of the tabularium where there is nearly no inner wall. The tabulae are incomplete with occasionally a more or less flat-topped axial part. They are interrupted by the axial ends of rather slender septa with a few spinose carinae.

There are 60 septa per corallite. The diameter of the tabularium varies between $11 \mathrm{~cm}$ and $12 \mathrm{~cm}$. The distances between the centres of adjacent corallites range from $33 \mathrm{~mm}$ to $55 \mathrm{~mm}$.

Discussion. The Mauritanian colony resembles the holotype of Iowaphyllum crassozonalum from which it differs by larger tabularia and greater distances between the centres of adjacent corallites. Additionally, the minor septa are restricted to the dissepimentarium in I. crassozonalum whereas its tabulae are typically compound with flat-topped axial parts. The Mauritanian form assigned to $I$. cf. crassozonalum resembles also I. schlueteri (Etheridge, 1898) which comes from the Givetian of New South Wales and North Queensland in Australia and which has been revised by Pedder et al. (1970, figs 6, 9) and Zhen (1994, p. 312). However, I. schlueteri is once more separated from the Mauritanian specimen by shorter distances between adjacent corallites and slightly smaller septal number and diameter of the tabularium. Moreover, $I$. schlueteri is characterized by thicker zones of stereoplasmic thickenings between the horizontal layers of dissepiments.

Distribution. Besides the questionable colony from the lower part of the Givetian in the Zemmour (Mauritania), Iowaphyllum crassozonalum is only known in the Givetian from the Sichuan Province in China.

\section{Stratigraphic and palaeobiogeographic conclusions}

The Givetian rugose coral fauna of the Zemmour is highly diversified though several species are only represented by a few specimens in the collection of Sougy (1964). At the specific level, there are curiously not many affinities with the Givetian material of the Tafilalt and the Ma'der in Morocco (Fig. 5) investigated recently by Pedder (1999), Schröder \& Kazmierczak (1999) and Coen-Aubert $(2005,2013)$. From a stratigraphic point of view, all the species of the Zemmour identified between units 87 and 100 of Sougy (1964) are typical of the Givetian stage.
In unit 87, Acanthophyllum heterophyllum, A. filiforme and Moravophyllum cf. ptenophylloides have been recognized in section D13 of Aguelt Oudiam el Khyam. M. ptenophylloides was originally described from the Lower Givetian of Moravia in the Czech Republic. Acanthophyllum heterophyllum is well known in the Upper Eifelian and the Lower Givetian from Belgium and France as well as from the Ma'der in Morocco where it has been described among others by Pedder (1999). As mentioned in the systematic part, A. filiforme is related to A. vermiculare which is associated with $A$. heterophyllum in Belgium and Germany and which has also been reported in the Lower Givetian of the Ma'der by Schröder \& Kazmierczak (1999). Argutastrea briceae is present in unit 87 from the section of Douik el Akhdar. All the original material of Rohart (1988) from the Boulonnais in France comes from the base of the Griset Member, in the lower part of Blacourt Formation. This level with $A$. briceae is still Lower Givetian on the basis of conodonts (Mistiaen et al., 2011). According to Coen (1985), the main part of the Griset Member in the Boulonnais can be correlated with the Mont d'Haurs Formation, on the south side of the Dinant Synclinorium in Belgium. This lithostratigraphic unit has been described among others by Coen-Aubert (1999, 2002). Finally, Phillipsastrea sobolewi and Iowaphyllum cf. crassozonalum have been recorded in unit 87 from section E4 of Tighirt. The Iowaphyllum form of the Zemmour resembles the Givetian species I. crassozonalum and I. schlueteri collected respectively in the Sichuan Province in China and in New South Wales and North Queensland in Australia. Phillipsastrea sobolewi occurs also at the base of unit 91 of Sougy (1964) and has been defined in the Middle Givetian of the Holy Cross Mountains in Poland (CoenAubert, 2013).

In section E4 of Tighirt, Siphonophrentis sp. and Sociophyllum isactis have been observed in unit 90 of Sougy (1964). The latter species is widely distributed in the Givetian of the Old World Realm (Fig. 5) and it is a good stratigraphic marker for this stage (Coen-Aubert, 1999). More precisely, $S$. isactis is common in the lower part of the Mont d'Haurs Formation, on the south side of the Dinant Synclinorium (Coen-Aubert, 1999, 2002) and it is associated with Iowaphyllum schlueteri in the Givetian of New South Wales (Pedder et al., 1970).

All the rest of the rugose coral fauna from the Zemmour comes from section F6 of Amgli el Harra and Amgli Zguilma, above unit 90 of Sougy (1964). At the base of this succession, Macgeea tourneuri and Phillipsastrea torreana are restricted to samples 2391 and 2392 (Fig. 4). As mentioned by CoenAubert (2013), P. torreana is known in the Givetian Portilla Formation from the Leon Province in Spain. Macgeea tourneuri is characterized by large coralla with stereoplasmic thickenings still developed in the tabularium of rather adult stages. Therefore, it is very different from other Macgeea such as $M$. crassiseptata Schröder, 2005 described from the Upper Givetian of the Ma'der by Schröder (2005b).

In the other samples of section F6, Acanthophyllum sougyi, Charactophyllum soraufi, C. mauritanicum and Phillipsastrea kergarvanensis are more or less frequent whereas Spinophyllum spongiosum and Siphonophrentis kullmanni are only represented by one specimen. S. kullmanni has also been introduced in
Figure 5. Occurrences of Givetian rugose corals from the Zemmour in different areas of the Old World Realm.

\begin{tabular}{|l|c|c|c|c|c|c|}
\hline & MOROCCO & $\begin{array}{c}\text { WESTERN } \\
\text { EUROPE }\end{array}$ & $\begin{array}{c}\text { EASTERN } \\
\text { EUROPE }\end{array}$ & RUSSIA & CHINA & AUSTRALIA \\
\hline Acanthophyllum heterophyllum & $\mathrm{x}$ & $\mathrm{x}$ & $\mathrm{x}$ & & & \\
Moravophyllum cf. ptenophylloides & & $\mathrm{x}$ & $\mathrm{x}$ & & & \\
Sociophyllum isactis & & $\mathrm{x}$ & $\mathrm{x}$ & $\mathrm{x}$ & $\mathrm{x}$ \\
Spinophyllum spongiosum & & $\mathrm{x}$ & & & & \\
Argutastrea briceae & & $\mathrm{x}$ & & & & \\
Phillipsastrea torreana & & $\mathrm{x}$ & & & & \\
Phillipsastrea kergarvanensis & & $\mathrm{x}$ & & & & \\
Phillipsastrea sobolewi & & & $\mathrm{x}$ & & & \\
Siphonophrentis kullmanni & & $\mathrm{x}$ & & & & \\
lowaphyllum cf. crassozonalum & & & & & $\mathrm{x}$ & \\
\hline
\end{tabular}


the Givetian Portilla Formation of the Leon Province. As for Spinophyllum spongiosum, it is another species characteristic for the top of the Lower Givetian in Belgium. Indeed, it is present in the lower part of the Mont d'Haurs Formation and at the top of the underlying of the Terres d'Haurs, on the south side of the Dinant Synclinorium (Coen-Aubert, 2002). Besides the Zemmour, Phillipsastrea kergarvanensis is abundant in the Upper Givetian of the Armorican Massif (Coen-Aubert, 2013). As discussed in the systematic part, the relations of the new species Acanthophyllum sougyi, Charactophyllum soraufi and $C$. mauritanicum with taxa of other countries are not very clear.

From a palaeogeographic point of view, the Zemmour was situated during the Givetian at the northern margin of Gondwana. This was also the case for the Ma'der in Morocco, the Leon Province in Spain and the Armorican Massif in France as explained by Coen-Aubert \& Plusquellec (2007) and Coen-Aubert (2013). This means that Phillipsastrea torreana, P. kergarvanensis and Siphonophrentis kullmanni are typically North Gondwanan species. Among the Givetian rugose corals from the Zemmour, there are additionally several species introduced in Eastern Europe and in other countries of Western Europe (Fig. 5) belonging to South Laurussia (Coen-Aubert \& Plusquellec, 2007). More particularly, Acanthophyllum heterophyllum, Sociophyllum isactis, Spinophyllum spongiosum and Argutastrea briceae are very useful for precise correlations between the Givetian of the Zemmour with that of Belgium, Germany and the Boulonnais in France. Farther to the east, there are only a few links with the Givetian of Russia, China and Australia (Fig. 5). These palaeogeographic relations for the Givetian rugose corals of the Zemmour are the same as those mentioned by Coen-Aubert $(2005,2013)$ for the Mauritanian Adrar and for the Ma'der and the Tafilalt in Morocco. Finally, it must be emphasized that the rather rare genera Moravophyllum, Charactophyllum and Iowaphyllum have been observed in the Givetian of the Zemmour.

\section{Acknowledgements}

Through the kindness of Dominique Laduron and Francis Tourneur, the rugose coral collection of Jean Sougy from the Zemmour in Mauritania, which was previously stored in the Institute of Geology at Louvain-la-Neuve, has been moved to the Collection of Palaeontology from the Institut royal des Sciences naturelles de Belgique in Brussels. Jean Sougy provided me stratigraphic data about several samples of the Zemmour, during the years 1991 and 1992. Weihua Liao (Nanjing) gave me interesting information about the holotype of Iowaphyllum crassozonalum He, 1978. Some recent thin sections have been made by Joël Laval at the Laboratory of successively Eddy Poty and Valentin Fischer (Liège). Wilfried Miseur and Thierry Hubin helped me with photography of the corals. Ross McLean and Anthony Wright reviewed very carefully the manuscript and improved the language. I am most grateful to all these persons.

\section{References}

Altevogt, G., 1967. Devonian tetracorals from Spain and their relation to North America species. In Oswald, D.H. (ed.), International Symposium on the Devonian System, Calgary, 1967, vol. 2. Alberta Society of Petroleum Geologists, Calgary, 755-769.

Barchy, L., Coen-Aubert, M., Marion, J.M. \& Coen, M., 2004. Mise en évidence de la Faille de Marenne sur la carte géologique Aye - Marche-en-Famenne. Bulletin de l'Institut royal des Sciences naturelles de Belgique, Sciences de la Terre, Supplément, 74, 5971.

Billings, E., 1858. Report for the year 1857 of E. Billings, Esq., Palaeontologist. Geological Survey of Canada, Report of Progress, 1857, 147-192.

Birenheide, R., 1961. Die Acanthophyllum-Arten (Rugosa) aus dem Richtschnitt Schönecken-Dingdorf und aus anderen Vorkommen in der Eifel. Senckenbergiana lethaea, 42, 77-146.

Birenheide, R., 1962. Revision der koloniebildenden Spongophyllidae und Stringophyllidae aus dem Devon. Senckenbergiana lethaea, 43, 41-99.
Birenheide, R., 1963. Cyathophyllum- und Dohmophyllum-Arten (Rugosa) aus dem Mitteldevon der Eifel. Senckenbergiana lethaea, 44, 363-458.

Birenheide, R., 1972. Ptenophyllidae (Rugosa) aus dem W-deutschen Mitteldevon. Senckenbergiana lethaea, 53, 405-437.

Birenheide, R., 1974. Grypophyllum frechi nom. nov. pro Grypophyllum mirabile Birenheide 1972. Fossil Cnidaria Newsletter, 1974/1, 7-8.

Birenheide, R., 1978. Rugose Korallen des Devon. In Krömmelbein, K. (ed.), Leitfossilien begründet von G. Gürich. 2., völlig neu bearbeitete Auflage, $n^{\circ} 2$. Gebrüder Borntraeger, Berlin, $265 \mathrm{p}$.

Birenheide, R., 1987. Erster Nachweis der rugosen Korallengattung Moravophyllum aus dem Ober-Eifelium der Eifel. Senckenbergiana lethaea, 67, 459-466.

Birenheide, R., 1998. Rugose und tabulate Korallen aus der Bohrung Viersen 1001. Fortschritte in der Geologie von Rheinland und Westfalen, 37, 161-213.

Birenheide, R. \& Kaya, O., 1987. Stratigraphy and Middle Devonian corals of the Adapazari area, N.W. Turkey. Senckenbergiana lethaea, 68, 263-303.

Birenheide, R. \& Lütte, B.P., 1990. Rugose Korallen aus dem MittelGivetium (Mittel-Devon) des Rheinischen Schiefergebirges. Senckenbergiana lethaea, 70, 1-28.

Brice, D., (ed.) 2016. Stratotype Givétien. Muséum national d'Histoire naturelle, Paris ; Biotope, Mèze, $272 \mathrm{p}$

Cao, X.D., Ouyang, X. \& Jin, T.A., 1983. Rugosa. In Xi'an Institute of Geology and Mineral Resources (ed.), Paleontological Atlas of Northwest China, Shaanxi, Gansu and Ningxia Volume. Part II Upper Palaeozoic. Geological Publishing House, Peking, 46179.

Coen, M., 1985. Ostracodes givétiens de l'Ardenne. Mémoires de l'Institut Géologique de l'Université de Louvain, 32, 1-48.

Coen-Aubert, M., 1990. Description de quelques Rugueux coloniaux du Couvinien supérieur de Wellin (bord sud du Bassin de Dinant, Belgique). Bulletin de l'Institut royal des Sciences naturelles de Belgique, Sciences de la Terre, 59, 15-35.

Coen-Aubert, M., 1997. Rugueux solitaires près de la limite EifelienGivetien à Pondrôme (Belgique). Bulletin de l'Institut royal des Sciences naturelles de Belgique, Sciences de la Terre, 67, 5-24.

Coen-Aubert, M., 1999. Description de quelques Rugueux coloniaux de la Formation givetienne du Mont d'Haurs en Ardenne. Bulletin de l'Institut royal des Sciences naturelles de Belgique, Sciences de la Terre, 69, 27-46.

Coen-Aubert, M., 2000. Stratigraphy and additional rugose corals from the Givetian Mont d'Haurs Formation in the Ardennes. Bulletin de l'Institut royal des Sciences naturelles de Belgique, Sciences de la Terre, 70, 5-23.

Coen-Aubert, M., 2002. Temnophyllids and Spinophyllids (Rugosa) from the Givetian Mont d'Haurs Formation in Belgium. Bulletin de l'Institut royal des Sciences naturelles de Belgique, Sciences de la Terre, 72, 5-24.

Coen-Aubert, M., 2005. Rugueux fasciculés et solitaires du Givetien supérieur dans le Tafilalt et le Ma'der (Maroc). Bulletin de l'Institut royal des Sciences naturelles de Belgique, Sciences de la Terre, 75, 67-85.

Coen-Aubert, M., 2011. Reassignment to the Middle Devonian of some rugose corals investigated by Le Maître (1934) in the Chalonnes Formation from the Southeastern Armorican Massif (France). Bulletin de l'Institut royal des Sciences naturelles de Belgique, Sciences de la Terre, 81, 27-53.

Coen-Aubert, M., 2013. Phillipsastreids and Ptenophyllids (Rugosa) from the Givetian of Mauritania and Northwestern Spain. Geologica Belgica, 16, 164-178.

Coen-Aubert, M. \& Lütte, B.P., 1990. Massive rugose corals from the Middle Devonian of the North Eifel Hills (Rheinisches Schiefergebirge, West Germany). Geologica et Palaeontologica, 24, 17-39.

Coen-Aubert, M. \& Lütte, B.P., 1993. Revision der rugosen Koloniekoralle Iowaphyllum rhenanum (Schlüter 1880) aus dem Oberdevon des Rheinischen Schiefergebirges (Deutschland). Paläontologische Zeitschrift, 67, 54-61.

Coen-Aubert, M. \& Plusquellec, Y., 2007. Nouvelles espèces du genre Phillipsastrea D'Orbigny, 1849 (Rugosa) dans le Givetien supérieur de la Rade de Brest (Massif Armoricain, France). Bulletin de l'Institut royal des Sciences naturelles de Belgique, Sciences de la Terre, 77, 63-75.

Crickmay, C.H., 1960. The older Devonian faunas of the Northwest Territories. Published by the author, Evelyn de Mille Books, Calgary, $21 \mathrm{p}$.

Dana, J.D., 1846. Genera of fossil corals of the family Cyathophyllidae. The American Journal of Science and Arts, series 2, 1, 178-189. 
Dumestre A. \& Illing, L.V., 1967. Middle Devonian reefs in Spanish Sahara. In Oswald, D.H. (ed.), International Symposium on the Devonian System, Calgary, 1967, vol. 2. Alberta Society of Petroleum Geologists, Calgary, 333-350.

Dybowski, W.N., 1873. Monographie der Zoantharia Sclerodermata Rugosa aus der Silurformation Estlands, Nord-Livlands und der Insel Gothland. Archiv für die Naturkunde Liv-, Est- und Kurlands, series 1, 5, 257-414.

Engel, G. \& Von Schouppé, A., 1958. Morphogenetisch-taxionomische Studie zur der devonischen Korallengruppe Stringophyllum, Neospongophyllum und Grypophyllum. Paläontologische Zeitschrift, 32, 67-114.

Etheridge, R., 1898. On the occurrence of the genus Endophyllum, Ed. and H. (emend. Schlüter) in the Lower Palaeozoic rocks of $\mathrm{N}$. S.Wales. Records of the Geological Survey of New South Wales, 6, 43-46.

Fenton, C.L. \& Fenton, M.A., 1924. The stratigraphy and fauna of the Hackberry Stage of the Upper Devonian. Contributions from the Museum of Geology, University of Michigan, 1, 1-260.

Frech, F., 1886. Die Cyathophylliden und Zaphrentiden des deutschen Mitteldevon. Palaeontologische Abhandlungen, 3/3, 1-120.

Frech, F., 1911. Das Devon Chinas. In Von Richtofen, F., China, Ergebnisse eigener Reisen und darauf gegründeter Studien, Bd. 5. Berlin, Dietrich Reimer, 18-58.

Galle, A., 2007. Spinophyllum Wedekind, 1922 (Anthozoa, Rugosa), in the Lower Givetian (Devonian) of the Bohemian Massif. Bulletin of Geosciences, 82, 133-144.

Goldfuss, A., 1826. Petrefacta Germaniae 1. Düsseldorf, Arnz \& Comp., 1-76.

Gürich, G., 1896. Das Palaeozoicum im Polnischen Mittelgebirge. Verhandlungen der Russisch-kaiserlichen Mineralogischen Gesellschaft zu St. Petersburg, serie 2, 32, 1-539.

Hall, J. \& Whitfield, R.P., 1873. Description of new species of fossils from the Devonian rocks of Iowa. Annual Report of the New York State Cabinet of Natural History, 23, 223-239.

He, Y.X., 1978. Subclass Rugosa. In Chengdu Institute of Geology and Mineral Resources (ed.), Atlas of fossils of Southwest China. Sichuan Volume. Part I, From Sinian to Devonian. Geological Publishing House, Beijing, 98-178.

Hill, D., 1939. The Devonian rugose corals of Lilydale and Loyola, Victoria. Proceedings of the Royal Society of Victoria, new series, 51, 219-256.

Hill, D., 1981. Part F, Coelenterata, Supplement 1, Rugosa and Tabulata, 2 vols. In Teichert, C. (ed.), Treatise on Invertebrate Paleontology. The Geological Society of America, and The University of Kansas, Boulder (Colorado) and Lawrence (Kansas), $762 \mathrm{p}$.

Ivania, V.A., 1955. O novom rode devonskikh korallov. Zametki po faune i flore Sibiri, 18, 85-86. [In Russian]

Ivania V.A., 1958. Novye vidy devonskikh korallov. Uchenye Zapiski Tomskogo Gosudarstvennogo Universiteta, 32, 100-106. [In Russian].

Jin, S.Y., 2005. Devonian coral identification and genera-species description. In Jin, S.Y., Shen, A., Chen, Z., Lu, J., Wei, M., Wang, Y. \& Xie, F. (eds), Mixed biostratigraphy of Devonian in Wenshan, Yunnan. Petroleum Industry Press, Hangzhou, 78-138.

Kettnerova, M., 1932. Paleontologicke studie z celechovickeho devonu, Cast IV: Rugosa. Prace geologicko-palaeontologickeho ustavu Karlovy university v Praze, 1932, 1-97.

Kong, L., 1981. Middle Devonian rugose corals in an organic reef from Dachang of Nandan District, Guangxi, Southern China. In Palaeontological Society of China (ed.), Selected Papers for $12^{\text {th }}$ Annual Conference of the Palaeontological Society of China. Science Press, Beijing, 50-60.

Kong, L. \& Huang, Y.M., 1978. Tetracoralla. In Guizhou Stratigraphy and Palaeontology Work Team (ed.), Palaeontological Atlas of Southwest China. Guizhou Volume. Part I, Cambrian-Devonian. Geological Publishing House, Beijing, 35-161.

Lesueur, C.A., 1821. Description de plusieurs animaux appartenant aux polypiers lamellifères de M. le $\mathrm{Ch}^{\text {er }}$ De Lamarck. Mémoires du Muséum d'Histoire naturelle, 6, 271-299.

Liao, W.H. \& Ma, X.P., 2017. Devonian corals from Zhaotong, NE Yunnan (2) - Givetian rugose corals. Acta Palaeontologica Sinica, 56, 68-81

Lütte, B.P., 1987. Glossophyllum-Arten aus dem Mittel-Devon der Eifel (Rugosa; Rheinisches Schiefergebirge). Senckenbergiana lethaea, 67, 433-457.

McLean, R.A., 2005. Phillipsastreid corals from the Frasnian (Upper Devonian) of Western Canada: Taxonomy and biostratigraphic significance. NRC Research Press, Ottawa, Ontario, 109 p.

McLean, R.A., 2010. Frasnian (Upper Devonian) colonial disphyllid corals from Western Canada. NRC Research Press, Ottawa, Ontario, 189 p.
McLean, R.A., 2014. Solitary disphyllid corals from the Frasnian (Upper Devonian) of western Canada. Palaeontographica Canadiana, 34, 1-123.

Merriam, C.W., 1973. Middle Devonian rugose corals of the Central Great Basin. U.S. Geological Survey Professional Paper, 799, $1-53$.

Milne-Edwards, H. \& Haime, J., 1851. Monographie des Polypiers fossiles des terrains paléozoïques. Archives du Muséum d'Histoire Naturelle, 5, 1-502.

Mistiaen, B., Brice, D., L.M. Hubert \& Loones, C., 2011. Field Trip 2: Classical Devonian and Carboniferous sites in the Ferques area, Boulonnais, Northern France. In Aretz, M. \& Poty, E. (eds), Field Guides, $11^{\text {th }}$ International Symposium on Fossil Cnidaria and Porifera, Liège, 2011. Kölner Forum für Geologie und Paläontologie, 20, 51-98.

O'Connell, M., 1914. Revision of the genus Zaphrentis. Annals of the New York Academy of Sciences, 23, 177-192.

Oliver, W.A., 1993. The Siphonophrentidae (rugose corals, Devonian) of Eastern North America. U.S. Geological Survey Bulletin, 2024, B1-B32.

Oliver, W.A. \& Galle, A., 1971. Rugose corals from the Upper Koneprusy Limestone (Lower Devonian) in Bohemia. Sbornik Geologickych Ved, Paleontologie, 14, 35-106.

Oliver, W.A. \& Sorauf, J.E., 1988. Heliophyllum Hall and Charisphyllum n. gen. (Devonian rugose corals) of the Cantabrian Mountains (NW Spain). Trabajos de Geologia, Universidad de Oviedo, 17, 3-17.

Pedder, A.E.H., 1982. Chostophyllum, a new genus of charactophyllid corals from the Middle Devonian of Western Canada. Journal of Paleontology, 56, 559-582.

Pedder, A.E.H., 1983. New Dalejan (Early Devonian) rugose corals from the Blue Fiord Formation of southwestern Ellesmere Island, Northwest Territories. Current Research, Part B, Geological Survey of Canada, 83-1B, 223-236.

Pedder, A.E.H., 1984. Dehiscens Zone corals from the Lower Devonian of Yukon Territory. Current Research, Part B, Geological Survey of Canada, 84-1B, 315-325.

Pedder, A.E.H., 1999. Paleogeographic implications of a Devonian (Givetian, Lower varcus Subzone) rugose coral fauna from the Ma'der Basin (Morocco). Abhandlungen der Geologischen Bundesanstalt, 54, 385-434

Pedder, A.E.H., Jackson, J.H. \& Ellenor, D.W., 1970. An interim account of the Middle Devonian Timor Limestone of NorthEastern New South Wales. Proceedings of the Linnean Society of New South Wales, 94, 242-272.

Pocta, P., 1902. Anthozoaires et Alcyonaires. In Barrande, J. (ed.), Système silurien du centre de la Bohême, 1 ère Partie: Recherches paléontologiques, 8 (2). Musée Bohême, Prague, 347 p.

Rafinesque, C.S. \& Clifford, J.D., 1820. Prodrome d'une monographie des Turbinolies fossiles du Kentucky (dans l'Amériq. septentr.). Annales générales des Sciences Physiques, 5, 231-235.

Roemer, C.F., 1883. Lethaea geognostica. I. Theil, Lethaea palaeozoica. Zweite Lieferung. Stuttgart, 324-543 and Atlas.

Rohart, J. C., 1988. Rugueux givetiens et frasniens de Ferques (Boulonnais-France). In Brice, D. (ed.), Le Dévonien de Ferques. Bas-Boulonnais (N. France). Biostratigraphie du Paléozoïque, 7 231-297.

Rozkowska, M., 1956. Pachyphyllinae from the Middle Devonian of the Holy Cross Mts. Acta Palaeontologica Polonica, 1, 271-322.

Schlüter, C., 1881. Über einige Anthozoen des Devon. Zeitschrift der Deutschen Geologischen Gesellschaft, 33, 75-108.

Schlüter, C., 1884. Über interessante neue Petrefakten. Verhandlungen des naturhistorischen Vereines der preussischen Rheinlande und Westfalens, 41, 79-84.

Schlüter, C., 1889. Anthozoen des rheinischen Mittel-Devon. Abhandlungen zur geologischen Specialkarte von Preussen und der Thüringischen Staaten, 8/4, 1-207.

Schröder, S., 1995. Die Korallenfauna des Kirchen-Berges (FreilingenFormation) in der Blankenheimer Mulde (Rheinisches Schiefergebirge/Eifel). Münstersche Forschungen zur Geologie und Paläontologie, 77, 373-421.

Schröder, S., 2001a. Wenig bekannte rugose Korallen aus dem Mittel-und Ober-Devon der Aachener Mulde (Rheinisches Schiefergebirge). Geologica et Palaeontologica, 35, 63-79.

Schröder, S., 2001b. On some western European Siphonophrentidae. Bulletin of the Tohoku University Museum, 1, 254-264.

Schröder, S., 2002. Rugose Korallen aus dem hohen Givetium und tiefen Frasnium (Devon) des Messinghäuser Sattels (Rheinisches Schiefergebirge/Sauerland). Coral Research Bulletin, 7, 175-189.

Schröder, S., 2005a. Stratigraphie und Systematik rugoser Korallen aus dem Givetium und Unter-Frasnium des Rheinischen Schiegergebirges (Sauerland/Bergisches Land). Zitteliana, B25, 39-116. 
Schröder, S., 2005b. Solitary Phillipsastreidae (Rugosa) from the Late Devonian of Europe and Northern Africa. Journal of Paleontology, 79, 871-883.

Schröder, S. \& Kazmierczak, M., 1999. The Middle Devonian "coral reef" of Ouihlane (Morocco) - New data on the geology and rugose coral fauna. Geologica et Palaeontologica, 33, 93-115.

Simpson, G.B., 1900. Preliminary descriptions of new genera of Paleozoic rugose corals. Bulletin of the New York State Museum, 8/37, 199-222.

Smith, S., 1945. Upper Devonian Corals of the Mackenzie River region, Canada. Special Papers Geological Society of America, 59, 1-126.

Song, X.L., 1974. Tetracorals. In Yunnan Geological Survey (ed.), Paleontological atlas of Yunnan. Yunnan People's Publishing House, Kunming, 109-191 and Atlas.

Sorauf, J.E., 1987. Upper Devonian (Frasnian) rugose corals from New York State. Journal of Paleontology, 61, 676-689.

Sorauf, J.E., 1998. Frasnian (Upper Devonian) rugose corals from the Lime Creek and Shell Rock Formations of Iowa. Bulletins of American Paleontology, 113/355, 1-159.

Soshkina, E.D., 1952. Opredelitel devonskikh chetyrekhluchevykh korallov. Trudy Paleontologicheskogo Instituta, 39, 1-127. [In Russian]

Soshkina, E.D., Dobrolyubova, T.A. \& Kabakovich, N.V., 1962. Podklass Tetracoralla. Chetyrekluchevye korally. In Orlov, Yu.A. (ed.), Osnovy Paleontologii, vyp. 2, Gubki, Arkheotsiaty, Kishechnopolostnye, chervi. Izdatelstvo Akademii Nauk SSSR, Moskva, 286-356. [In Russian].

Sougy, J. 1964. Les formations paléozoïques du Zemmour noir (Mauritanie septentrionale). Etude stratigraphique, pétrographique et paléontologique. Annales de la Faculté des Sciences, Université de Dakar, 15, 1-695.

Stumm, E.C., 1949. Revision of the families and genera of the Devonian tetracorals. The Geological Society of America, Memoir, 40, 1-92.

Stumm, E.C., 1960. New rugose corals from the Middle and Upper Devonian of New York. Journal of Paleontology, 34, 161-163.

Stumm, E.C., 1964. Silurian and Devonian corals of the Falls of the Ohio. The Geological Society of America, Memoir, 93, 1-184.

Sytova, V.A., Tchudinova, I.I. \& Ulitina, L.M. 1974. Devonskaya Sistema. Korallovye polipy. In Akopyan, V.T. (ed.), Atlas iskopaemoy fauny Armyanskoy SSR. Izdatelstvo AN Armyanskoy SSR, Erevan, 31-45. [In Russian].

Torley, K., 1933. Über Endophyllum bowerbanki M. Ed. u. H. Zeitschrift der Deutschen Geologischen Gesellschaft, 85, 630633.

Tourneur, F., 1987. Zemourella, nouveau genre de Tabulé du Dévonien moyen du Zemmour Noir (Mauritanie septentrionale). Geologica et Palaeontologica, 21, 51-71.

Wang, H.C., 1948. The Middle Devonian rugose corals of Eastern Yunnan. Contributions from the Geological Institute, National University of Peking, 33, 1-45.

Webster, C.L., 1889. Description of a new genus of corals from the Devonian rocks of Iowa. The American Naturalist, 23/272, 710712 .

Wedekind, R., 1922. Zur Kenntnis der Stringophyllen des oberen Mitteldevon. Sitzungsberichte der Gesellschaft zur Beförderung der gesamten Naturwissenschaften zu Marburg, 1921/1, 1-16.

Wedekind, R., 1923. Die Gliederung des Mitteldevons auf Grund von Korallen. Sitzungsberichte der Gesellschaft zur Beförderung der gesamten Naturwissenschaften zu Marburg, 1922, 24-35.

Wedekind, 1924. Das Mitteldevon der Eifel. Eine biostratigraphische Studie. I. Teil. Die Tetrakorallen des unteren Mitteldevon. Schriften der Gesellschaft zur Beförderung der gesamten Naturwissenschaften zu Marburg, 14/3, 1-93.

Wedekind, R., 1925. Das Mitteldevon der Eifel. Eine biostratigraphische Studie. II. Teil. Materialien zur Kenntnis des mittleren Mitteldevon. Schriften der Gesellschaft zur Beförderung der gesamten Naturwissenschaften zu Marburg, 14/4, 1-85.

Wendt, J. \& Kaufmann, B., 2006. Middle Devonian (Givetian) coralstromatoporoid reefs in West Sahara (Morocco). Journal of African Earth Sciences, 44, 339-350.

Wrzolek, T., 2002. Siphonophrentidae (Rugosa) in the Devonian of Poland. Coral Research Bulletin, 7, 229-240.

Wrzolek, T. \& Wach, P., 1994. Tetracoral genus Spinophyllum in the Devonian of the Holy Cross Mts, Poland. Geologia, 12/13, 47-63.

Yu, C.M. \& Kuang, G.D., 1982. Late Middle Devonian rugose corals from Liujing, Heng Xian, Guangxi and their paleoecological signifiance. Bulletin of the Nanjing Institute of Geology and Palaeontology, Academia Sinica, 4, 241-278.
Zhen, Y.Y., 1994. Givetian rugose corals from the northern margin of the Burdekin Basin, north Queensland. Alcheringa, 18, 301-343.

Zhen, Y.Y. \& Jell, J.S, 1996. Middle Devonian rugose corals from the Fanning River Group, North Queensland, Australia. Palaeontographica, Abteilung A, 242, 15-98.
Manuscript received 08.08.2017, accepted in revised form 10.10.2017, available on line 12.12.2017. 

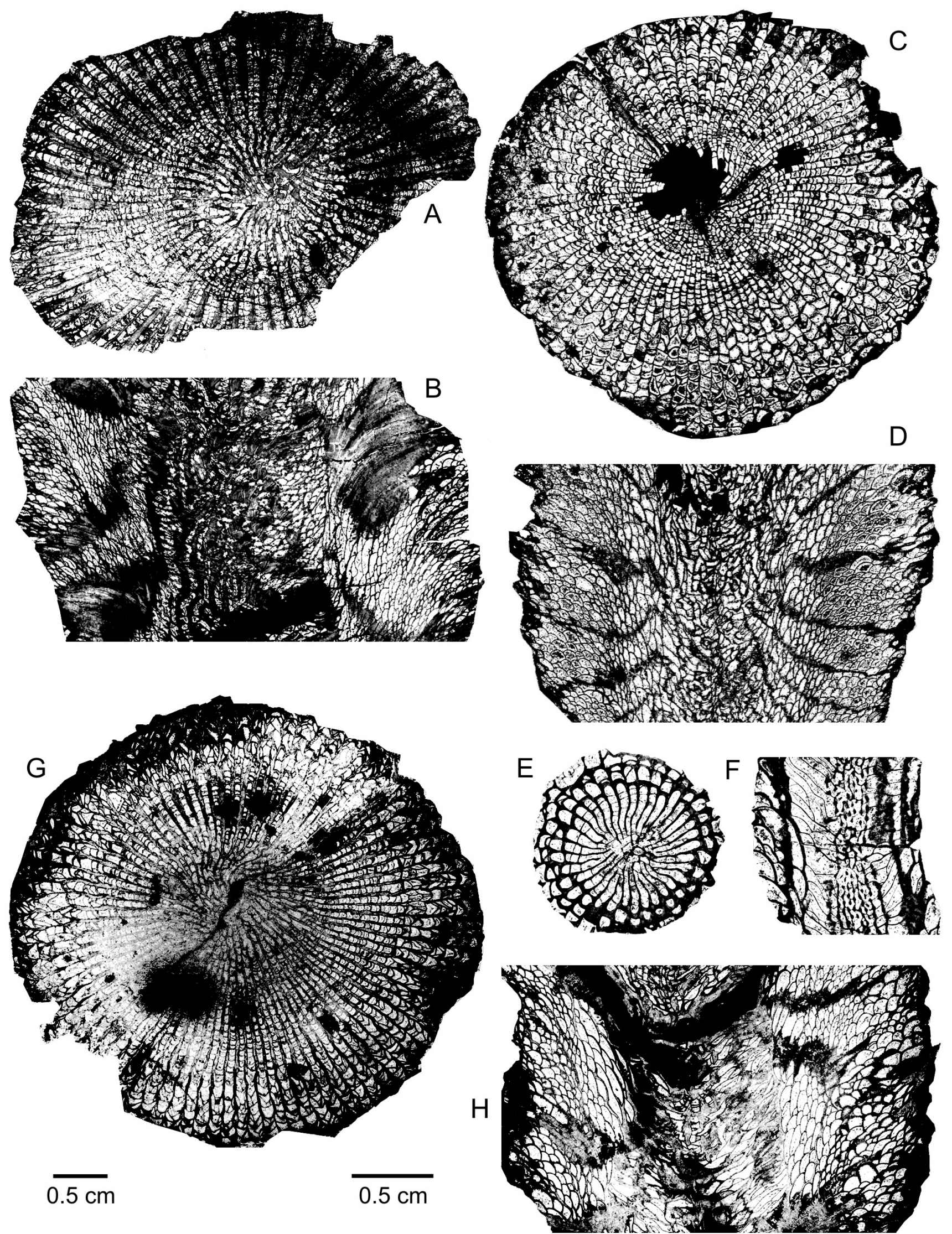

Plate 1. A-B: Acanthophyllum heterophyllum (Milne-Edwards \& Haime, 1851). IRScNB a13142, Zemmour 5544B 1. 9160-I; transverse and longitudinal sections. C-D: Acanthophyllum filiforme n. sp. Holotype, IRScNB a13143, Zemmour 5544B 1. 9160-II; transverse and longitudinal sections. E-F: Sociophyllum isactis (Frech, 1886). IRScNB a13149, Zemmour 5552K-MAU45; transverse and longitudinal sections. G-H: Acanthophyllum sougyi n. sp. Holotype, IRScNB a13145, Zemmour 2381D 1. 9144-I; transverse and longitudinal sections. Magnification x 2 for figures A-D, G-H and x 3 for figures E-F. 

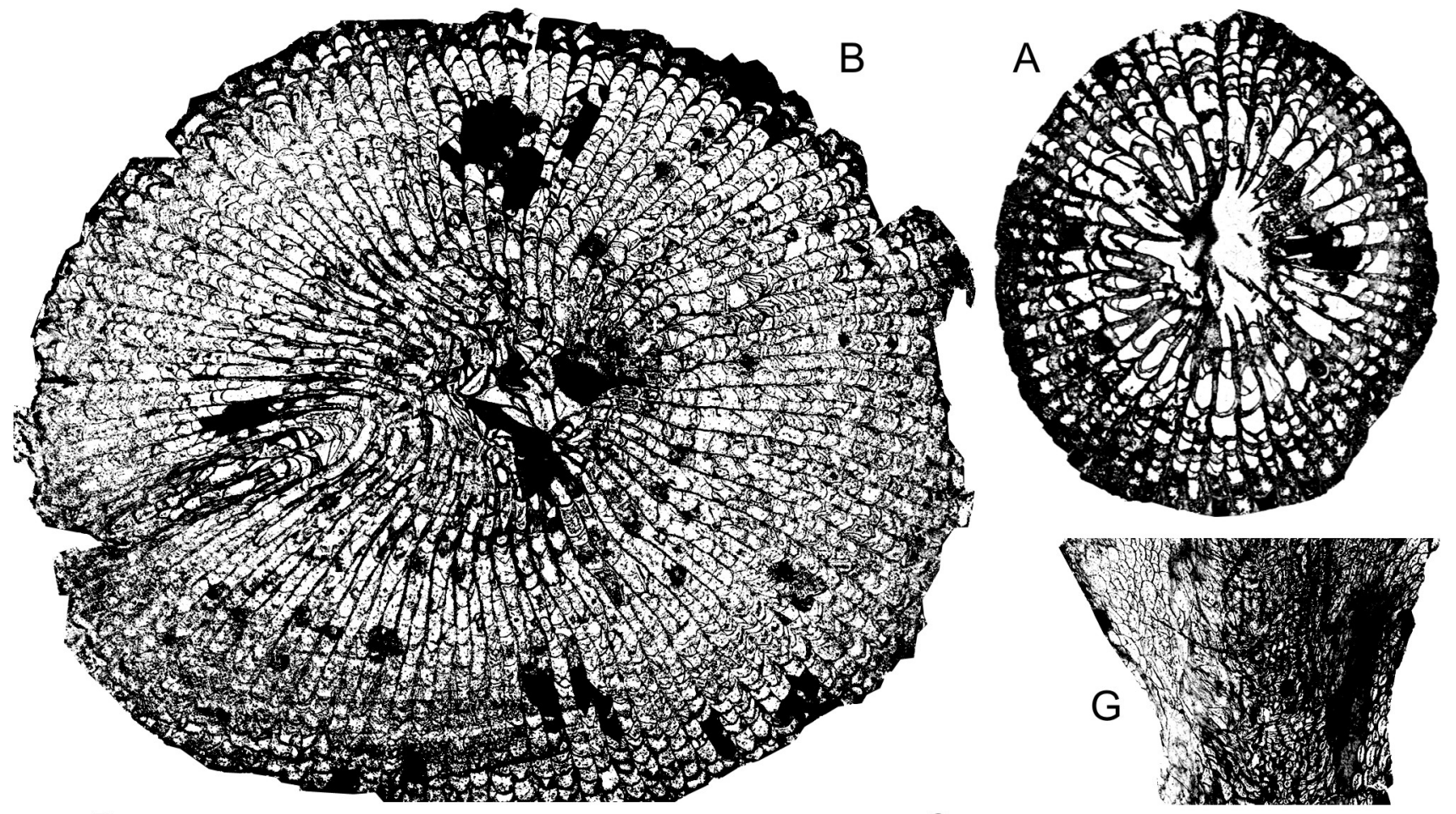

D

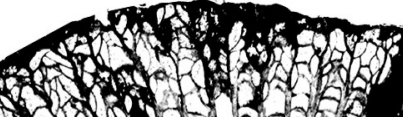

121

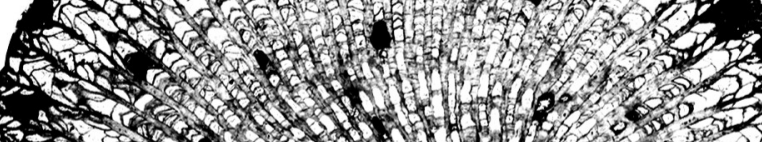

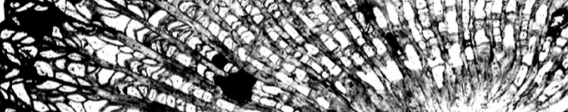

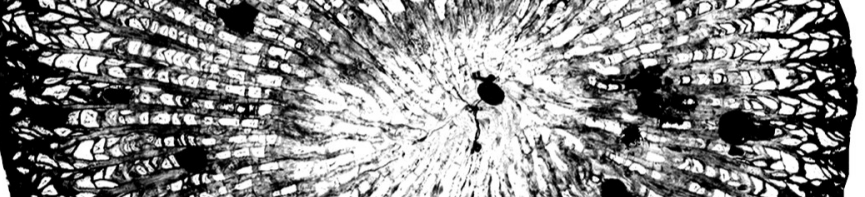

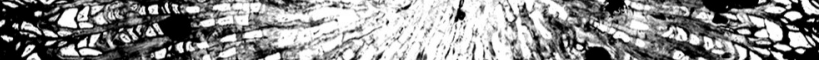

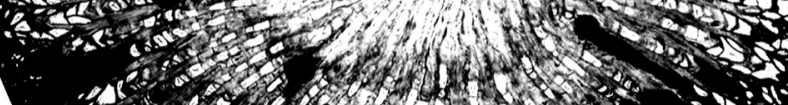
-

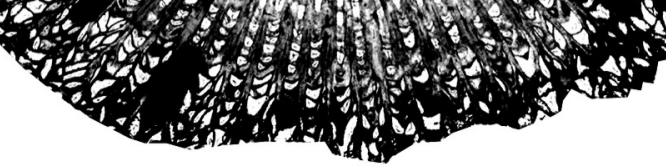

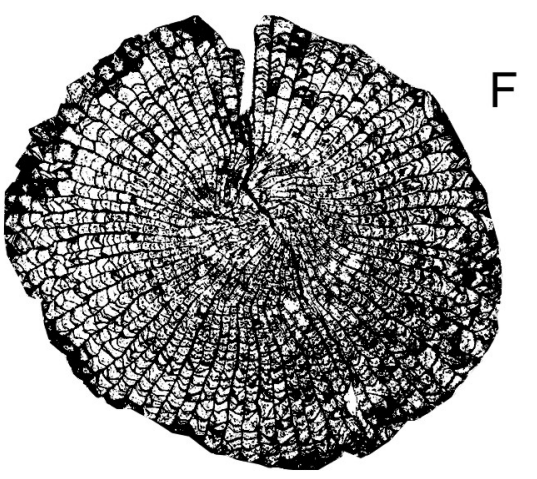

\section{(3)}

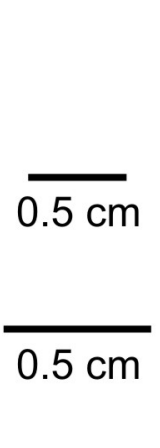

E
C

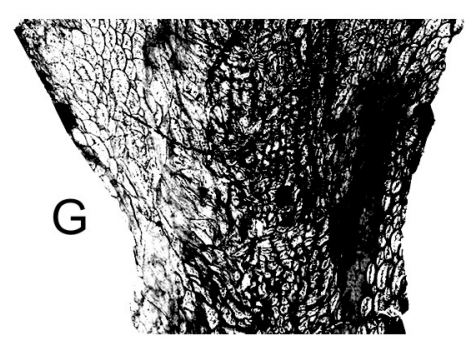

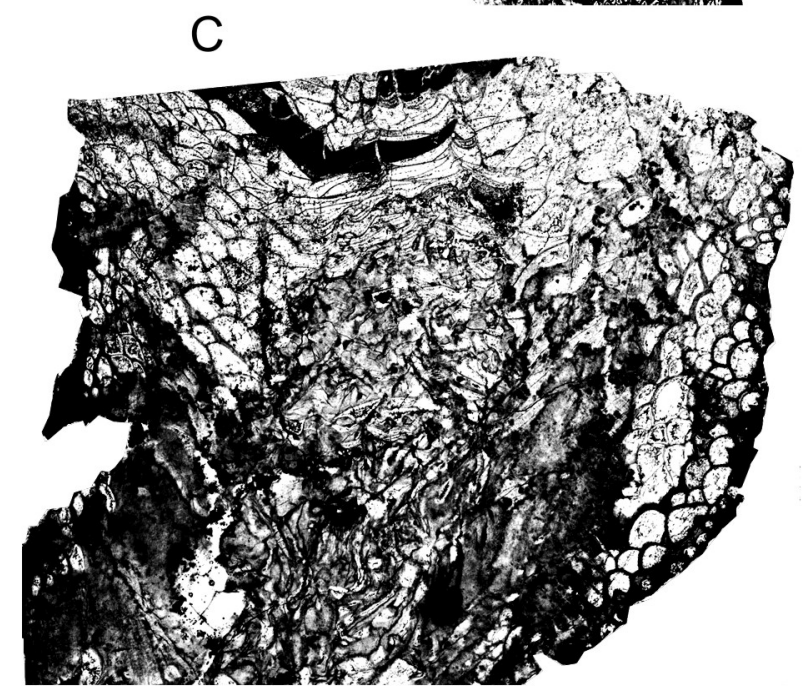

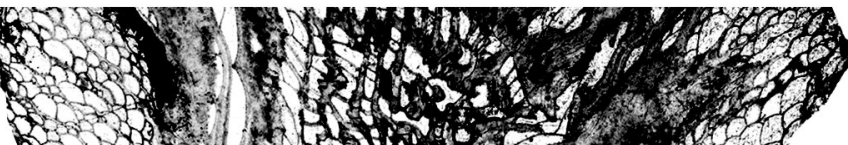

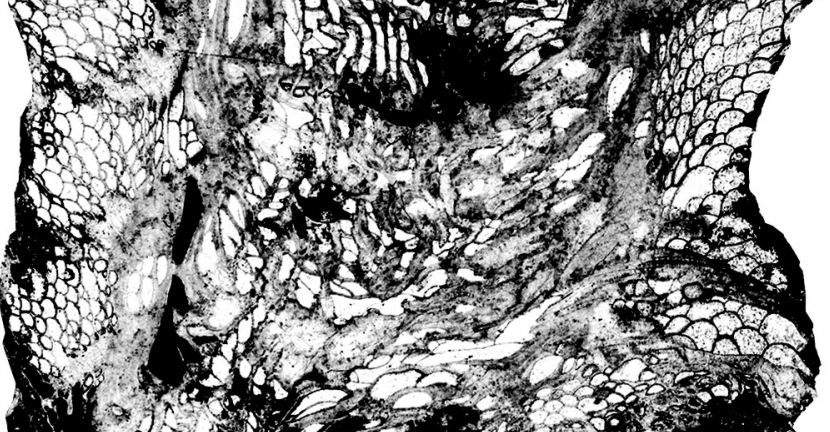

Plate 2. A: Charactophyllum soraufi n. sp. Paratype, IRScNB a13151, Zemmour 2381D-MAU35; transverse section. B-C : Moravophyllum cf. ptenophylloides Kettnerova, 1932. IRScNB a13148, Zemmour 5544G 1.9166 ; transverse and longitudinal sections. D-E: Acanthophyllum sougyi n. sp. Paratype, IRScNB a13146, Zemmour 2396 1. 7167-II ; transverse and longitudinal sections. F-G : Acanthophyllum filiforme n. sp. Paratype, IRScNB a13144, Zemmour 5544F 1. 9168-II ; transverse and longitudinal sections. Magnification x 2 for figures B-G and x 3 for figure A. 


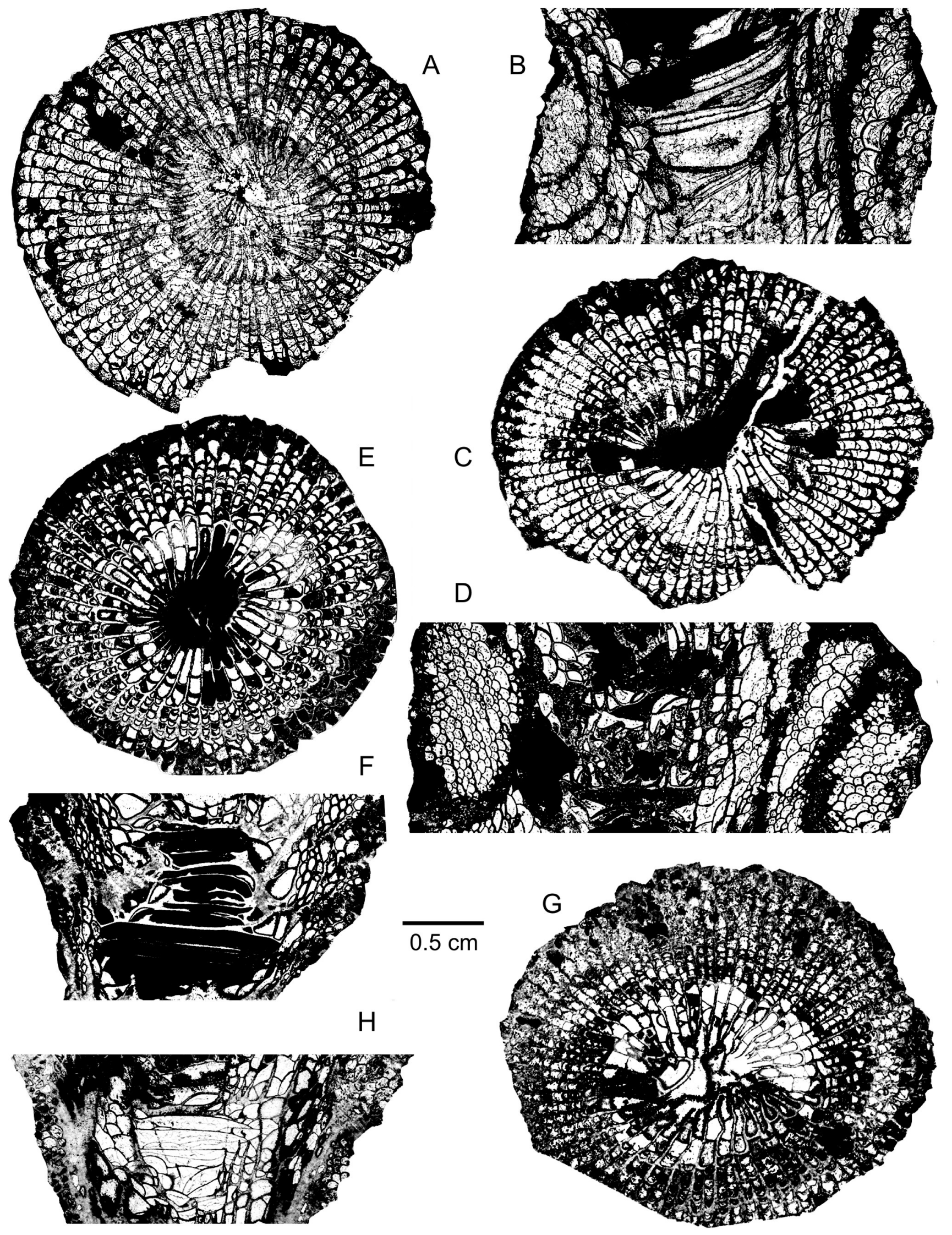

Plate 3. A-D: Charactophyllum mauritanicum n. sp. A-B: Holotype, IRScNB a13154, Zemmour 2398 1. 7168-III ; transverse and longitudinal sections. C-D: Paratype, IRScNB a13155, Zemmour 2398 1. 7168-I ; transverse and longitudinal sections. E-H: Charactophyllum soraufi n. sp. E-F: Holotype, IRScNB a13150, Zemmour 2381D-MAU34; transverse and longitudinal sections. G-H: Paratype, IRScNB a13152, Zemmour 2381D 1. 9144-IV; transverse and longitudinal sections. Magnification x 3 . 

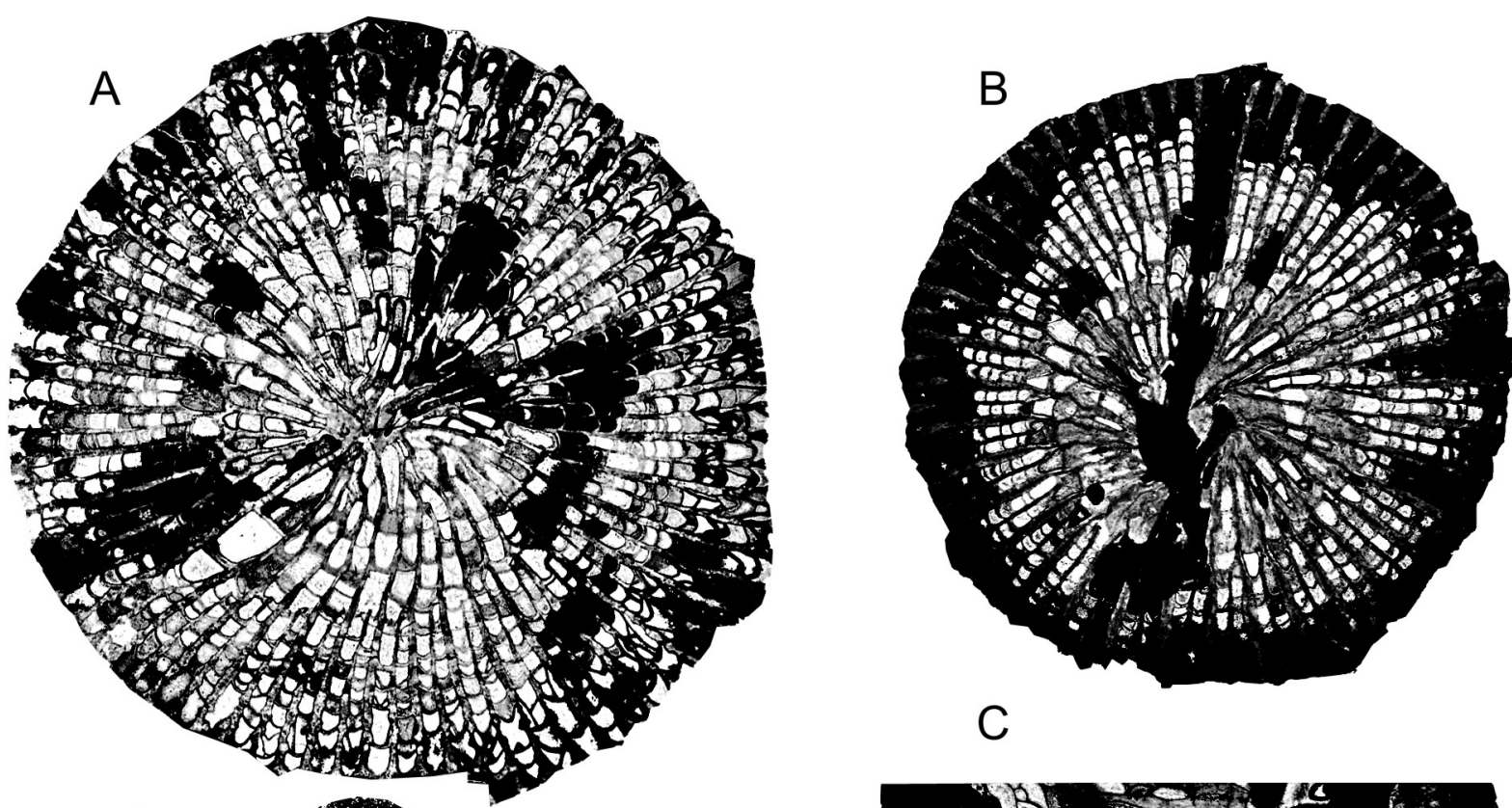

C

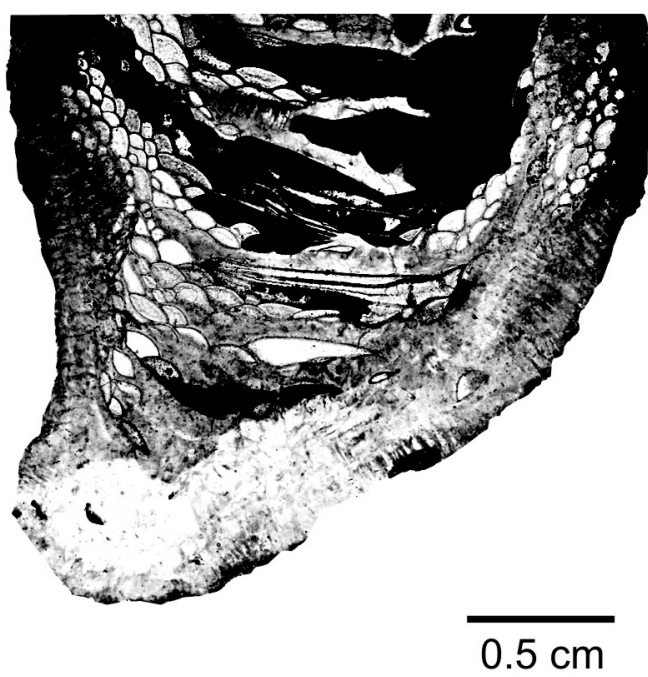

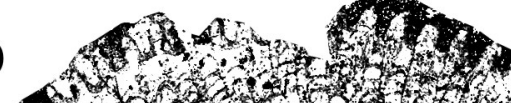

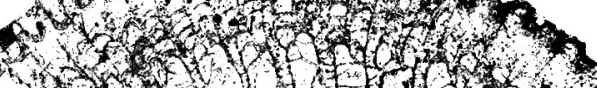

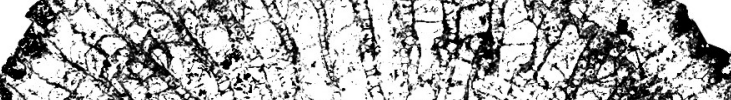

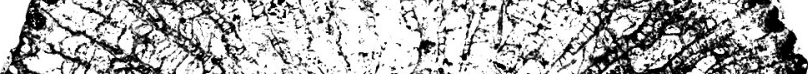

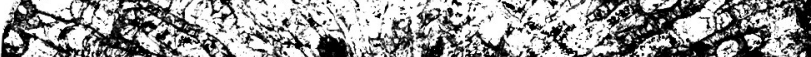

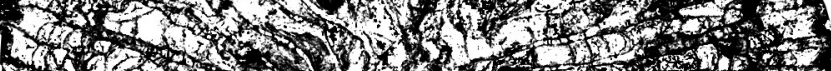

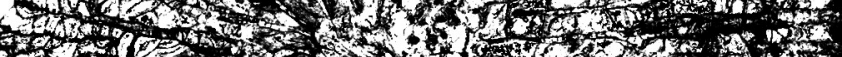

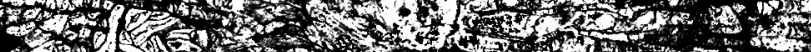

1.

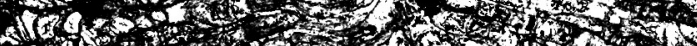

S3.

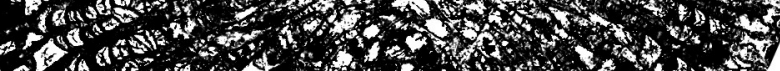

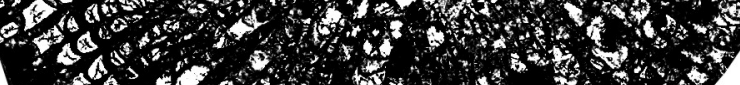

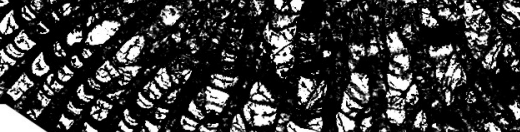

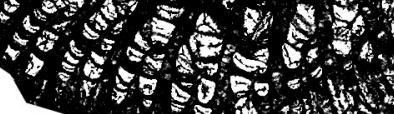

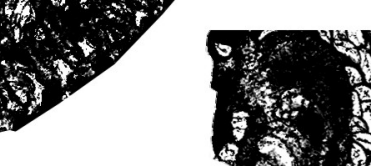

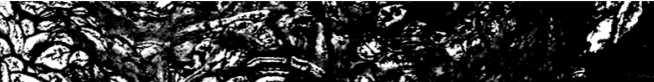

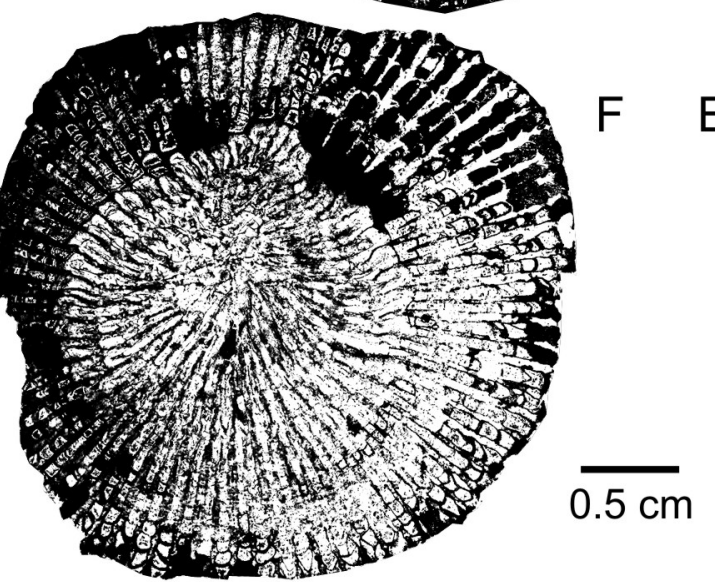

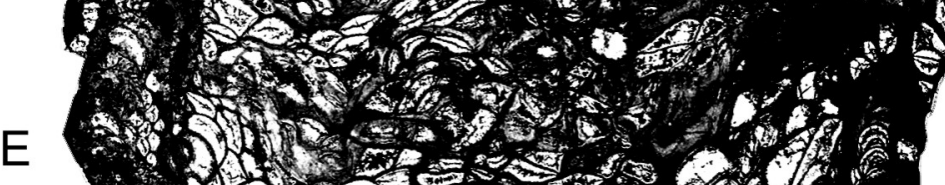<smiles>C1=CC=[Ge]=1</smiles>
$7 \mathrm{2} 20 \%$

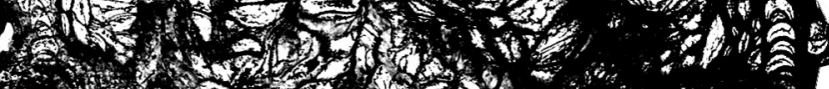

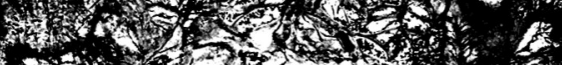
5. 100,5$)$

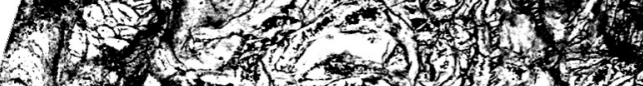

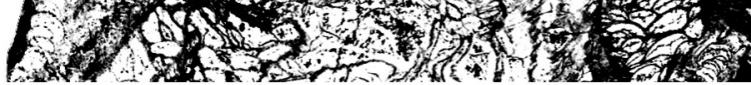

Plate 4. A-C: Charactophyllum mauritanicum n. sp. A: Paratype, IRScNB a13156, Zemmour 2389-MAU21; transverse section. B-C: Paratype, IRScNB a13157, Zemmour 2389-MAU25 ; transverse and longitudinal sections. D-E: Macgeea tourneuri n. sp. Holotype, IRScNB a13160, Zemmour 23911. 7108-V; transverse and longitudinal sections. F: Acanthophyllum sougyi n. sp. Paratype, IRScNB a13147, Zemmour 2413 1. 7170-IV; transverse section. Magnification $\mathrm{x} 2$ for figure $\mathrm{F}$ and $\mathrm{x} 3$ for figures A-E. 


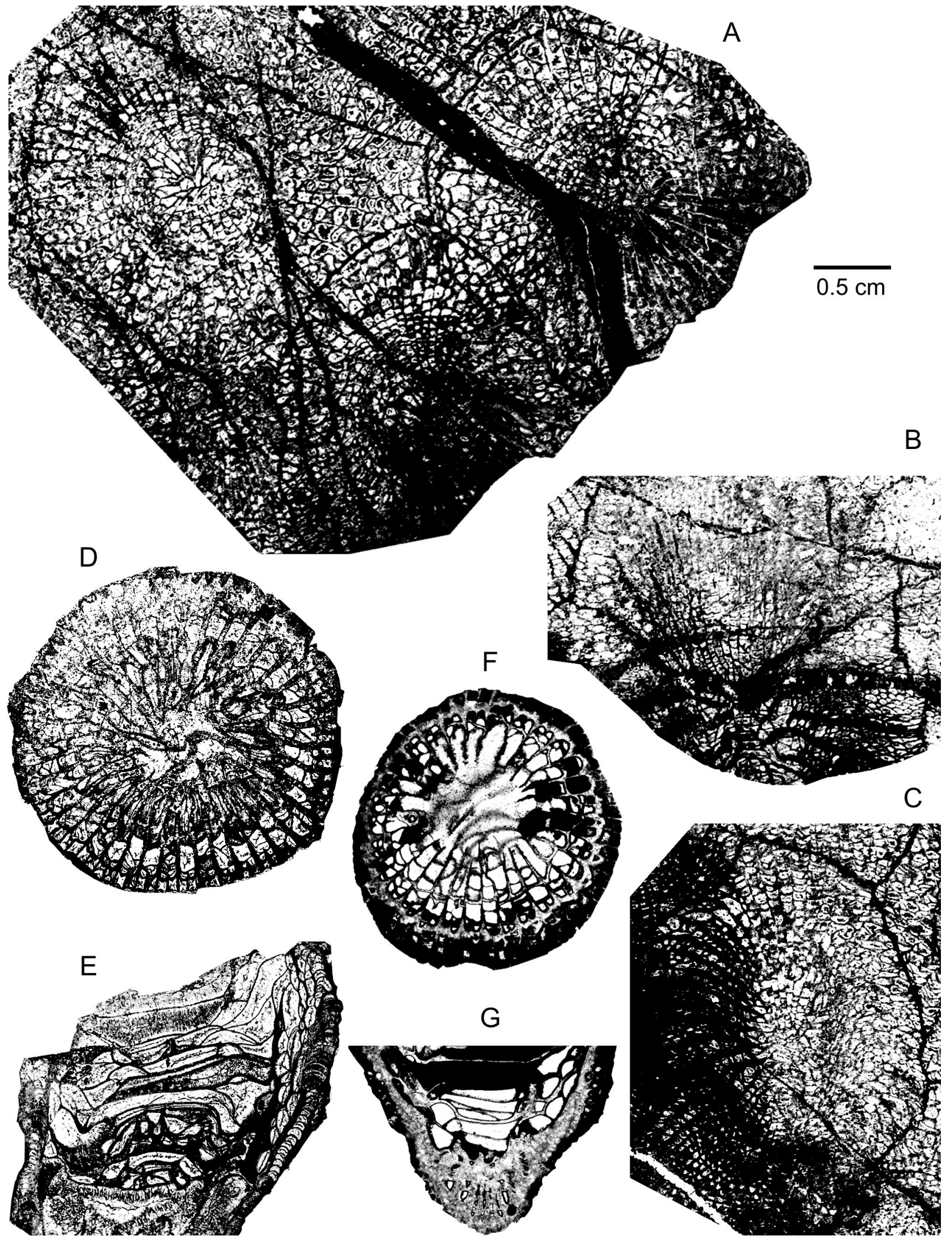

Plate 5. A-C: Argutastrea briceae (Rohart, 1988). IRScNB a13159, Zemmour 4171.9137 ; transverse and longitudinal sections. D-E: Macgeea tourneuri n. sp. Paratype, IRScNB a13161, Zemmour 2391 1. 7108-I ; transverse and longitudinal sections. F-G: Charactophyllum soraufin. sp. Paratype, IRScNB a13153, Zemmour 2381D-MAU37 ; transverse and longitudinal sections. Magnification x 3. 

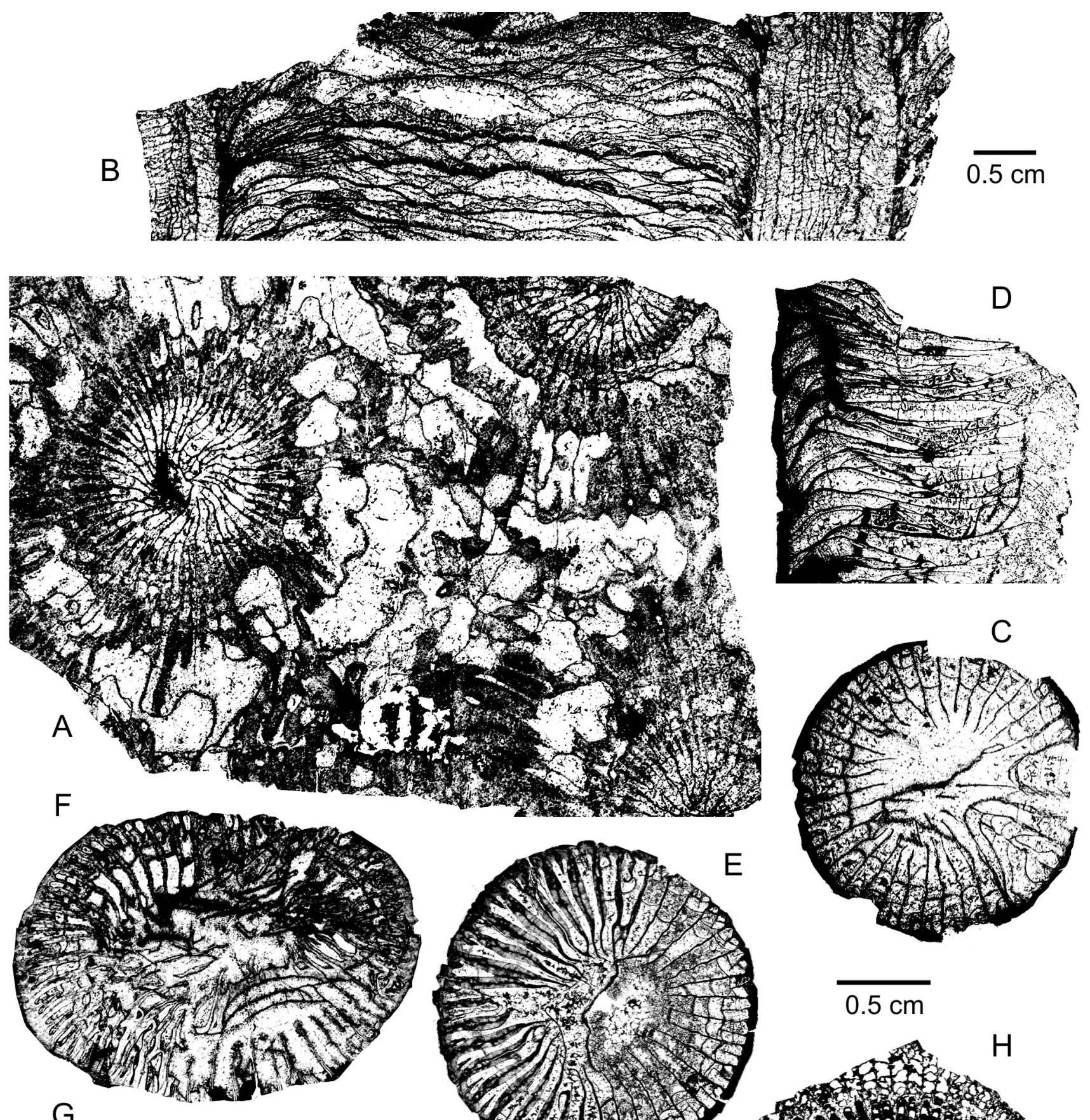

G
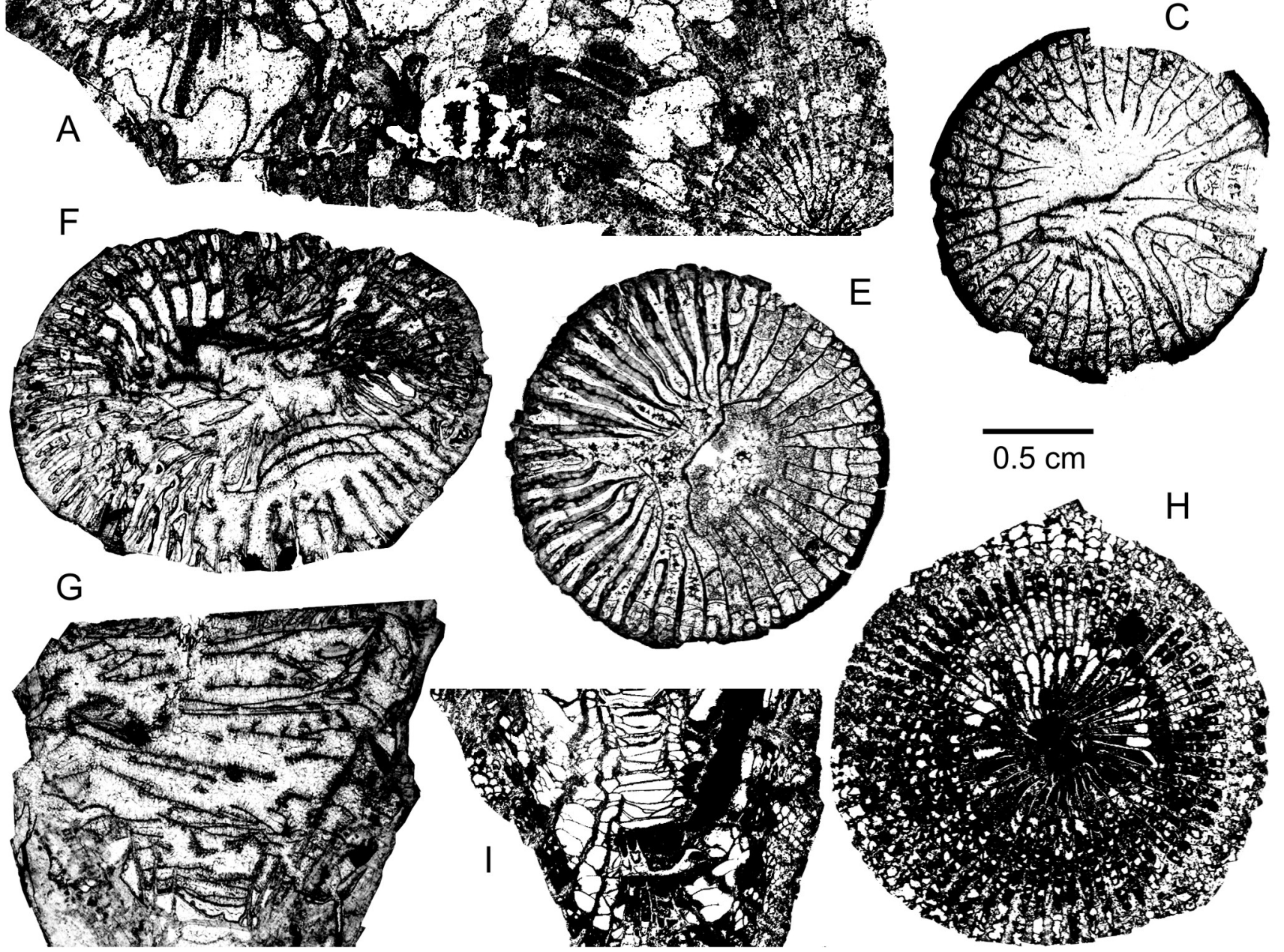

Plate 6. A-B: Iowaphyllum cf. crassozonalum He, 1978. IRScNB a3397, Zemmour 53141.9112; transverse and longitudinal sections. C-E: Siphonophrentis sp. C-D: IRScNB a13163, Zemmour 5552K 1. 9186-I ; transverse and longitudinal sections. E: IRScNB a13164, Zemmour 5552K-MAU43; transverse section. F-G: Siphonophrentis kullmanni (Birenheide, 1978). IRScNB a13162, Zemmour 2381D 1. 9144-III ; transverse and longitudinal sections. H-I: Spinophyllum spongiosum (Schlüter, 1889). IRScNB a13158, Zemmour 2381D-MAU33 ; transverse and longitudinal sections. Magnification x 2 for figures $\mathrm{A}-\mathrm{G}$ and $\mathrm{x} 3$ for figures $\mathrm{H}-\mathrm{I}$. 